\title{
Improvement of the mechanical properties of titanium carbonitride-metal composites by modification of interfaces
}

\author{
Hanjung Kwon ${ }^{\dagger}$ \\ Division of Advanced Materials Engineering, Jeonbuk National University, Jeollabuk-do, 54896, Republic of Korea \\ 계면 개선을 통한 타이타늄 탄/질화물 금속 복합재료의 기계적 물성 향상 \\ 권한중 \\ 전북대학교 신소재공학부
}

(Received May 18, 2020; Accepted June 2, 2020)

\begin{abstract}
Fracture in the titanium carbonitride-metal composites occurs by crack propagation through the carbonitride grains or in the interfaces. Thus, intrinsic properties of the carbonitride need to be enhanced and the interfaces should be also modified to coherent structure to strengthen the composites. Especially, interfacial structure can be the main factor to determine the mechanical properties of titanium carbonitridemetal composites because the interfaces between carbonitride grains and metallic phase are weak parts due to heterogeneous nature of carbonitride and metallic phase. In this paper, methodologies for improving the interfacial structure of titanium carbonitride-metal composites are suggested. Total area of the interfaces can be reduced using solid solution type carbonitrides as raw materials instead of a mixture of various carbonitrides in the composites. Also, synthesis of titanium carbonitride-metal composite powders and the low-temperature sintering of the composite powders for short time can be the way for formation of coherent interfaces. The sintering of the composite powders for short time at low temperature can reduce the potential of formation of interfaces by dissolution and precipitation of carbonitride in the liquid metal. As a result of formation of coherent boundaries due to low-temperature and short-time sintering, interfaces between titanium carbonitride grains and metallic phase have the favorable structure for the enhanced fracture toughness. It is believed that the low-temperature sintering of solid solution type composite powders for short
\end{abstract}

${ }^{\dagger}$ Corresponding Author: Hanjung Kwon

E-mail: hjkwon@jbnu.ac.kr 
time can be the way to improve the low toughness of the titanium carbonitride-metal composites.

Keywords: Composite, Cermet, Fracture toughness, Interface, Mechanical properties

\section{1. 서론}

탄/질화물 금속 복합재료는 금속 원소와 비금속 원소 (탄소 및 질소)의 강한 공유결합으로 융점이 높아 고온 및 부식성 환경에서 안정한 특성을 갖는 탄/질화물과 연 성이 우수하여 가공이 쉽고 열/전기 전도성이 우수한 금 속 물질이 복합화되어 있는 소재로 탄/질화물과 금속의 장점을 모두 활용할 수 있다는 것이 특징이다. 특히 탄/ 질화물 금속 복합재료는 구조용 제품에서 세라믹스 소 재에 비해 제조가 용이하고 금속에 비해 고온 안정성, 내부식성이 우수하여 기존 소재의 한계 극복 및 활용 범 위 확장을 위한 소재로 활용되고 있다 ${ }^{1)}$.

탄/질화물 금속 복합재료의 대표적인 예로는 전이 금속의 탄/질화물과 니켈, 코발트가 복합화되어 있 는 서멧트가 있다. 서멧트는 세라믹(Ceramic)과 금속 (Metal)의 합성어로 경도가 높고 내마모 특성이 우수한 탄/질화물과 같은 세라믹스 물질과 파괴에 대한 저항성 이 큰 금속 물질의 특성을 갖고 있어 고온 환경과 마찰 이 극심한 부분에 적용되는 소재이다. 서멧트의 활용 분 야는 절삭공구, 금형, 압연 롤 등이 있으며 이 활용 분 야는 모두 사용 시 마찰이 심하고 고온 환경이 유발된다 는 특징이 있다. 절삭공구의 경우 자동차 엔진과 같은 기계 부품을 가공하기 위한 도구로 기계 부품의 원자재 인 철강 소재와의 마찰로 인하여 고온이 유발되기 때문 에 고온 안정성이 중요하며 철강 소재에 대한 절삭과 다 듬질에 적합한 고경도 물질로 제조되어야 한다. 또한 파 괴에 취약한 절삭공구는 수명이 짧다는 단점이 있어 절 삭공구 활용도를 높이고 수명을 길게 하기 위해서 원재 료에 금속 성분이 추가되게 된다. 이러한 이유로 절삭공 구의 소재로 서멧트가 사용되고 있으며 절삭공구의 수 명을 향상시키기 위해 서멧트에서는 경도, 내마모 특성 이외에 파괴인성이라는 공구 수명과 관련된 기계적 물 성 또한 중요하다.
서멧트의 미세조직은 세라믹 물질인 탄/질화물 입자 들과 탄/질화물 입자들 사이에 금속 성분(니켈, 코발트) 이 분포되어 있는 형태이며 서멧트가 부품 소재로 사용 될 때 파괴는 탄/질화물 입자들이 깨지거나 탄/질화물 입자와 금속 성분 간 계면에서 균열이 발생하면서 일어 나게 된다. 따라서 서멧트의 파괴에 대한 저항성(파괴인 성)을 향상시키기 위한 연구는 탄/질화물 입자에 대한 강화와 탄/질화물 입자와 금속 성분 간 계면의 특성 향 상의 2 가지 측면에서 이루어져야 한다. 본 논문에서는 서멧트의 파괴인성을 향상시키기 위한 계면 개선 관련 연구에 대해 소개하고자 한다.

\section{2. 본론}

\section{1. 서멧트의 미세조직 및 물성}

서멧트를 구성하는 탄/질화물 물질로는 텅스텐 탄화 물, 타이타늄 탄/질화물이 대표적이며 금속 성분으로 는 니켈과 코발트가 서멧트에 포함된다. 텅스텐 탄화 물과 타이타늄 탄/질화물은 녹는점이 각각 $2,870{ }^{\circ} \mathrm{C}$ , $3160{ }^{\circ} \mathrm{C}$ 로 서멧트를 제조하는 소결 공정의 온도인 1400 $1500{ }^{\circ} \mathrm{C}$ 에서 고체 상태를 유지하고 니켈과 코발 트와 같은 금속 성분은 녹는점이 각각 $1455{ }^{\circ} \mathrm{C}, 1495{ }^{\circ} \mathrm{C}$ 로 소결 중 최종 온도에서 액체 상태로 변화하게 된다. 결국 소결을 통해 제조된 서멧트의 미세조직에서 텅스

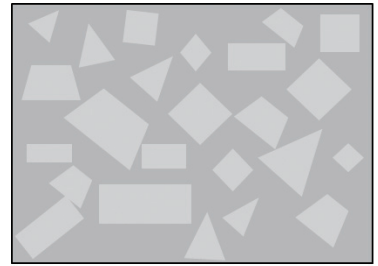

WC Co

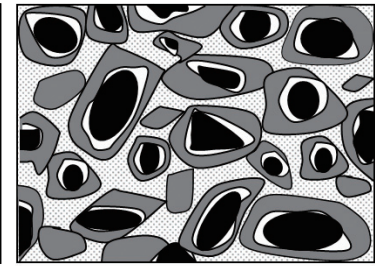

$\square \mathrm{Ti}(\mathrm{CN})$
Fig. 1. Microstructure of cermets: (a) WC-Co and (b) Ti(CN)-Ni cermet 


\section{특 집 표 권한중}

텐 탄화물과 타이타늄 탄/질화물은 입자로 남아있고 금 속 성분은 입자 형태를 잃어버려 탄/질화물 입자 사이에 분포하게 된다. Fig. 1은 서멧트의 미세조직을 모식적으 로 나타낸 것으로 탄/질화물 입자가 금속 성분에 분포되 어 있는 형태인 것을 확인할 수 있다 ${ }^{2-4)}$. 텅스텐 탄화물 이 포함된 서멧트의 경우 소결 온도에서 용해되지 않은 탄화물 입자들은 각진 형태를 갖고 타이타늄 탄/질화물 이 포함된 서멧트에서 탄/질화물 입자는 불규칙적인 형 태를 나타낸다. 서멧트는 소결 온도에서 액상이 존재하 는 액상 소결에 의해 제조되는데 액상 소결 과정 중 탄/ 질화물 입자의 형태는 탄/질화물 입자의 계면 에너지의 이방성과 관련이 있다. 즉, 육방정계의 결정계에 속하는 텅스텐 탄화물의 경우 면에 따른 계면 에너지의 차이가 크고 액상 소결 과정 중 계면 에너지가 낮은 면의 성장 이 빠르게 이루어지기 때문에 각진 입자 형태를 나타내 며 면에 따른 계면 에너지 차이가 크지 않은 경우 둥근 형태의 입자가 형성되게 된다. 타이타늄 탄/질화물 기반 서멧트는 Fig. 1(b)에서 볼 수 있듯이 입자의 형태가 단 순하지 않고 코어-림 구조를 갖는 것을 알 수 있는데 이 는 타이타늄 탄/질화물 기반 서멧트의 경우 물성 보완 및 생산성 향상을 위해 여러가지 첨가 원소가 포함되기 때문이다. 타이타늄 탄/질화물은 텅스텐 탄화물에 비해 탄/질화물 내 금속 성분과 비금속 성분 간 결합력이 크 고 열역학적 안정성이 높아 경도는 우수하나 인성은 상 대적으로 낮아 타이타늄 탄/질화물을 원료로 제조되는 서멧트는 텅스텐 탄화물로부터 제조되는 서멧트에 비해
쉽게 깨지는 단점이 있다. 또한 타이타늄 탄/질화물은 서멧트에 포함되는 금속 성분과의 친화도가 낮아 $(\mathrm{Ni}$ 과 의 젖음각: 약 $30^{\circ}$ ) 타이타늄 탄/질화물 기반 서멧트는 소결성이 떨어지고 완전하게 치밀화된 소결체 제조가 상대적으로 용이하지 않다. 즉, 액상 소결 시 소결 온도 에서 액상의 금속이 타이타늄 탄/질화물 입자 사이의 공 간으로 침투가 용이하지 않아 고밀도 소결체를 얻기가 쉽지 않다. 타이타늄 탄/질화물 기반 서멧트에서는 위와 같은 물성과 제조 공정에서의 불리함을 보완하기 위해 다양한 전이금속 혹은 전이금속 탄/질화물이 추가되게 된다. 추가되는 물질로는 몰리브데넘 금속과 바나듐, 나 이오븀, 탄탈럼 등의 탄/질화물이 있으며 이렇게 추가되 는 원소 혹은 화합물은 액상 소결 과정 중 용해-재석출 이 동시에 일어나지 않게 된다. 즉, 상대적으로 안정한 물질은 용해 속도가 작고 불안정한 물질은 용해 속도가 큰 것이다. 타이타늄 탄/질화물의 안정성이 가장 높고 타이타늄 탄/질화물이 서멧트 내 가장 많은 양이 포함 되어 있으므로 소결 시 액상에 용해된 성분들은 용해되 지 않은 타이타늄 탄/질화물 입자 주변에서 고용상을 형 성하면서 석출하고 코어-림 조직을 형성한다. Fig. 1에 서 알 수 있듯이 텅스텐 탄화물계 서멧트에 비해 타이타 늄 탄/질화물 기반 서멧트의 경우 코어-림 조직으로 인 해 계면 면적이 큰 것을 알 수 있으며 계면의 특성이 타 이타늄 탄/질화물계 서멧트의 파괴 거동과 전체적인 물 성에 지대한 영향을 미칠 것이라 예상할 수 있다.

표 1은 서멧트의 기계적 물성을 문헌 조사를 통해 정

Table 1. Mechanical properties of cermets ${ }^{2-12}$

\begin{tabular}{c|c|c|c}
\hline \multicolumn{2}{|c|}{ Material } & $\begin{array}{c}\text { Hardness } \\
\left(\mathrm{H}_{\mathrm{v}}, \mathrm{GPa}\right)\end{array}$ & $\begin{array}{c}\text { Fracture toughness } \\
\left(\mathrm{K}_{\mathrm{IC}}, \mathrm{MPa} \cdot \mathrm{m}^{1 / 2}\right)\end{array}$ \\
\hline \multirow{4}{*}{ Cermet } & $\mathrm{TiC}-\mathrm{Ni}$ & 9.2 & 7.4 \\
\cline { 2 - 4 } & $\mathrm{Ti}(\mathrm{CN})-\mathrm{WC}-\mathrm{Ni}$ & $9.1 \sim 14$ & $10 \sim 7.2$ \\
\cline { 2 - 4 } & $\mathrm{WC}-\mathrm{Co}$ & $12.5 \sim 18.3$ & $16.4 \sim 8$ \\
\hline \multirow{5}{*}{ Ceramics } & $(\mathrm{Ti}, \mathrm{W}) \mathrm{C}$ & 20.5 & 7.7 \\
\cline { 2 - 4 } & $\mathrm{TiC}-\mathrm{WC}$ & 18 & 5.5 \\
\cline { 2 - 4 } & $\mathrm{Al}_{2} \mathrm{O}_{3}-\mathrm{SiC}$ & 17.9 & 3.3 \\
\cline { 2 - 4 } & $\mathrm{Si}_{3} \mathrm{~N}_{4}-\mathrm{SiC}$ & 16.6 & 5.2 \\
\cline { 2 - 4 } & $\mathrm{Si}_{3} \mathrm{~N}_{4}-\mathrm{TiN}$ & 15.0 & 7.6 \\
\hline
\end{tabular}




\section{재료별 시장 점유율}

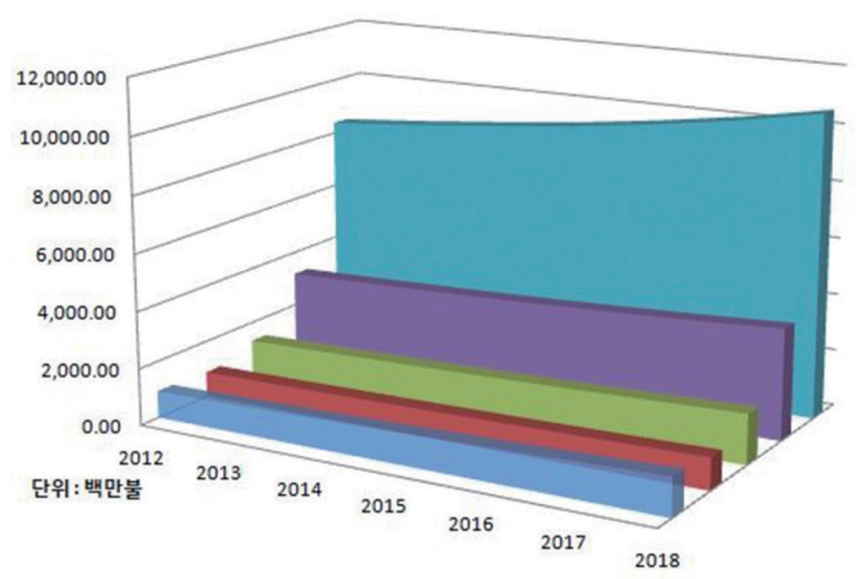

- $\mathrm{cBN} / \mathrm{PcBN}$

- 타이타늄 탄질화물계 서멧트

| 세라믹

- 고속도강

| 텅스텐 탄화물계 서멧트

Fig. 2. Global market for cutting tools ${ }^{13)}$

리한 표로 비교를 위하여 세라믹스 소재의 물성을 제시 하였다 ${ }^{2-12)}$. 서멧트 내에서는 타이타늄 탄/질화물 계열 의 소재가 텅스텐 탄화물 기반 소재에 비해 파괴인성이 낮은 것을 확인할 수 있으며 타이타늄 탄/질화물 물질 의 자체적인 파괴인성이 텅스텐 탄화물에 비해 낮은 것 과 Fig. 1에 나타낸 것처럼 미세조직 상 계면 면적이 큰 것이 타이타늄 탄/질화물계 서멧트의 낮은 인성의 원인 이 될 수 있다 ${ }^{3-4)}$. 이와 같은 이유로 서멧트가 절삭공구 와 같은 부품에 적용될 때 텅스텐 탄화물계 소재가 타이
타늄 탄/질화물계 소재에 비해 부품 수명에서 유리할 것 임을 예상할 수 있다. 즉, 텅스텐 탄화물계 소재의 파괴 인성이 타이타늄 탄/질화물계 소재와 비교하여 우수하 기 때문에 텅스텐 탄화물계 소재의 파괴에 대한 저항력 이 타이타늄 탄/질화물계 소재에 비해 우월하고 결과적 으로 텅스텐 탄화물계 소재가 적용된 부품이 더 긴 수명 을 나타내는 것이다. 실제로 절삭공구 시장에서 점유율 을 확인해보면 Fig. 2와 같이 텅스텐 탄화물계 소재가 전체 시장의 약 $53 \%$ 를 점유하고 있으나 타이타늄 탄/질

\section{Transgranular Fracture}

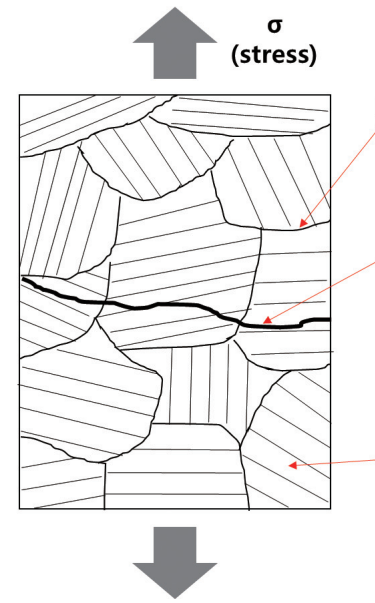

\section{Intergranular Fracture}

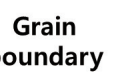

Fracture

through

grains

Individual grain

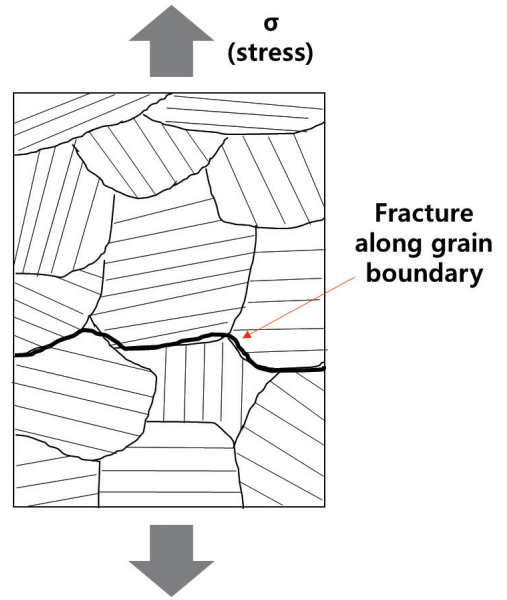

Fig. 3. Types of fracture in ceramics 
화물계 소재는 $10 \%$ 미만의 시장 규모를 갖는 것을 알 수 있다 ${ }^{13)}$. 이는 타이타늄 탄/질화물이 텅스텐 탄화물에 비 해 밀도가 낮아 제품 당 원료 가격이 낮다는 타이타늄 탄/질화물계 소재의 장점에도 불구하고 타이타늄 탄/질 화물계 소재의 낮은 물성이 절삭공구에서 타이타늄 탄/ 질화물계 소재의 적용에 걸림돌이 되고 있음을 의미한 다. 또한 타이타늄 탄/질화물계 소재의 물성을 고경도 세라믹스 소재의 물성과 비교해보면 파괴인성 측면에서 는 타이타늄 탄/질화물계 서멧트가 세라믹스 소재에 비 해 우위에 있지만 경도는 횔씬 낮은 것을 알 수 있다. 이 러한 이유로 타이타늄 탄/질화물계 서멧트는 고경도 특 성이 필요한 분야(금형, 내마모 부품 등)에서도 세라믹 스 소재에 자리를 뺏기고 있어 적용 범위를 넓히는 것에 도 한계가 있다.

\section{2. 서멧트의 파괴거동}

세라믹스 소결체의 파괴 시 미세조직 상 균열의 전파 는 Fig. 3 과 같이 입내 파괴와 입계 파괴의 2 가지 양상 으로 진행된다. 입내 파괴에서는 파괴 시 균열은 입자 를 통해서 진행되게 되며 균열의 방향은 각 입자들의 원 자 배열에 따라서 변화하게 된다. 즉, 균열이 진행하면 서 균열은 결정 방향 중 가장 균열 전파가 쉬운 방향을 따라서 움직이고 새로운 입자를 통과할 때에는 입자의 방향이 달라지므로 균열 진행 양상은 Fig. 3에서 알 수 있듯이 입자의 방향에 따라 달라지게 되는 것이다. 입내 파괴는 입자들이 맞닿고 있는 경계를 따라서 균열이 진 행하는 것이고 입계에서 강도가 약하고 취성이 강한 물 질에서 주로 발생된다 ${ }^{14-15)}$.

세라믹스 물질과 금속 물질이 복합화 되어 있는 서멧 트의 경우 금속 성분의 양이 적은 경우 이외에 대부분의 계면은 세라믹스 입자와 금속 성분 간 계면인 세라믹/금 속 계면으로 이루어져 있다. 세라믹스 소결체와 달리 서 멧트의 경우 계면이 이종 성분들이 접하여 형성되기 때 문에 재료의 파괴 중 균열 전파에 대한 기여도가 클 수 있으며 서멧트의 파괴인성을 향상시키기 위해서는 서멧 트를 구성하는 물질들의 특성을 개선하는 것보다 계면 에 대한 강화가 더 효과적일 수 있다.

\section{3. 서멧트 내 입자 강화 연구}

서멧트의 파괴인성을 향상시키기 위한 방법으로 서멧 트를 구성하는 탄/질화물 입자를 강화시키는 방법이 있 다. 서멧트를 구성하는 금속 성분은 소성 변형이 용이하 여 외부에서 주어지는 응력을 흡수하기 쉬워 균열 전파 가 잘 되지 않는다. 즉, 서멧트에서는 금속 성분을 통한 균열보다는 탄/질화물 입자의 균열이 용이하기 때문에 서멧트의 파괴인성을 개선하기 위해서는 탄/질화물과 같은 세라믹스 입자의 강화가 필요한 것이다.

서멧트 내 탄/질화물 입자의 강화는 주로 타이타늄 탄/질화물계 서멧트에서 많은 연구가 진행되었는데 이 는 앞서 언급한 것처럼 타이타늄 탄/질화물의 낮은 인 성으로 타이타늄 탄/질화물을 원료로 제조되는 서멧트 의 파괴인성이 낮기 때문이다. 타이타늄 탄/질화물의 파 괴인성 특성을 향상시키기 위한 방법으로 고용을 통한 특성 개선이 있으며 이 방법에서는 기존에 원료로 사용 되던 $\mathrm{Ti}(\mathrm{CN})$ 형태의 단순 타이타늄 탄/질화물 대신 타 이타늄 이외의 전이금속이 고용된 형태인 $(\mathrm{Ti}, \mathrm{M})(\mathrm{CN})$ $(\mathrm{M}=\mathrm{W}, \mathrm{Mo}, \mathrm{Nb}, \mathrm{V}, \mathrm{Ta}$ 등 $)$ 상을 서멧트 원료로 사용하 게 된다 ${ }^{5)}$. 고용된 형태의 타이타늄 탄/질화물은 단순 타 이타늄 탄/질화물에 비해 고용 강화 효과로 강도 및 파 괴인성이 우수하다. 앞서 언급한 것처럼 타이타늄 탄/ 질화물계 서멧트는 우수한 화학적 안정성과 높은 경도 및 낮은 가격 등의 장점을 갖고 있지만 텅스텐 탄화물 계 소재보다 강도, 파괴인성, 내열 충격성 등이 열등하 여 주로 강재의 마무리 가공에 적용 분야가 한정되어 왔 다. 즉, 타이타늄 탄/질화물계 서멧트 공구의 경우 가공 후 미려한 피조물의 면조도로 부품 생산 공정의 후공정 단축 및 고속 정밀 가공이 가능하여 공정원가 및 환경적 인 면에서도 텅스텐 탄화물계 소재에 비해 효과가 월등 하지만 텅스텐 탄화물계 소재에 비해 낮은 인성으로 중 절삭 분야에서 사용이 제한되어 타이타늄 탄/질화물계 서멧트 공구의 세계 시장 점유율이 미비한 것이다. 현재 고용된 형태의 타이타늄 탄/질화물계 서멧트 원료를 개 발하고 있는 국내 기업은 없으며 대학과 연구원에서의 기술 개발만이 진행된 상태이다.

여러 가지 방법을 통해 고용된 형태의 타이타늄 탄/ 
Table 2. Mechanical properties of the cermets prepared from solid solution type titanium carbonitride ${ }^{16-24)}$

\begin{tabular}{c|c|c}
\hline Material & $\begin{array}{c}\text { Hardness } \\
\left(\mathrm{H}_{\mathrm{v}}, \mathrm{GPa}\right)\end{array}$ & $\begin{array}{c}\text { Fracture toughness } \\
\left(\mathrm{K}_{\mathrm{IC}}, \mathrm{MPa} \cdot \mathrm{m}^{1 / 2}\right)\end{array}$ \\
\hline$(\mathrm{Ti}, \mathrm{Mo}) \mathrm{C}$ & 19.1 & 7.6 \\
\hline$(\mathrm{Ti}, \mathrm{Al}, \mathrm{V})(\mathrm{CN})$ & 20.6 & 6.2 \\
\hline$(\mathrm{Ti}, \mathrm{Mo}, \mathrm{Si})(\mathrm{CN})$ & 17.5 & 7.7 \\
\hline$(\mathrm{Ti}, \mathrm{Cr}) \mathrm{C}$ & 20.3 & 12.5 \\
\hline$(\mathrm{Ti}, \mathrm{W}) \mathrm{C}-\mathrm{Ni}$ & 10.6 & 9.5 \\
\hline Nano TiC-TiAl3 & 22.7 & 11.9 \\
\hline$(\mathrm{Ti}, \mathrm{Nb})(\mathrm{CN})-\mathrm{Ni}$ & 13.2 & 10.7 \\
\hline$(\mathrm{Ti}, \mathrm{V}) \mathrm{C}-\mathrm{Ni}$ & 12.6 & 16.6 \\
\hline
\end{tabular}

질화물을 제조할 수 있지만 가장 많이 연구되고 선호되 는 기술은 고에너지 밀링을 이용한 분말 제조 방법이다. 이 방법에서는 타이타늄을 비롯한 금속 성분과 탄소 및 질소를 밀링 과정을 통해 반응시키거나 타이타늄 산화 물을 원료에 대해 밀링을 이용한 혼합 분쇄 과정 후 고 온 열처리를 통하여 고용된 타이타늄 탄/질화물을 제조 하게 된다. 높은 순도와 우수한 특성을 보유한 고용 타 이타늄 탄/질화물을 제조하기 위해서는 밀링 효과가 탁 월한 유성 볼밀링 (planetary ball milling) 법을 사용하 는데, 장비의 특성상 공정 스케일 업이 용이하지 않다. 현재 국내 최고 수준은 한국지질자원연구원에서 개발한 batch 당 $3 \mathrm{~kg}$ 제조 공정이며 특히 타이타늄 스크랩을 활용하여 제조 원가를 낮춘 것이 핵심이다.

고용된 형태의 타이타늄 탄/질화물을 원료로 하여 서 멧트를 제조하게 되면 미세조직은 Fig. 4에 나타낸 것처 럼 기존 서멧트 대비 계면의 면적이 적은 구조로 변화하 게 된다. 기존 타이타늄 탄/질화물계 서멧트의 경우 여 러 종류의 탄화물이 포함되므로 용해되지 않은 상과 용 해된 성분들의 고용상이 코어-림 조직을 형성하지만 고 용된 형태의 타이타늄 탄/질화물을 원료로 서멧트가 제 조되면 소결 과정 중 용해-재석출이 동일한 조성으로 이루어지기 때문에 Fig. 4의 오른쪽 Fig. 과 같이 단일상 의 미세조직이 형성되게 된다. 이러한 구조의 타이타늄 탄/질화물계 서멧트는 기존 서멧트와 달리 계면의 면적 이 줄어든 것과 고용 강화된 탄/질화물의 물성 향상 효
과로 인해 개선된 파괴인성을 나타낼 것이라 예상할 수 있다. 표 2 는 고용된 형태의 타이타늄 탄/질화물을 원료 로 하여 제조된 세라믹스 소결체 및 서멧트의 특성을 나 타낸 것으로 표 1 의 기존 타이타늄 탄/질화물계 서멧트 의 파괴인성과 비교해보면 고용된 타이타늄 탄/질화물 계 서멧트에서 파괴인성이 향상되는 것을 알 수 있으며 텅스텐 탄화물계 소재와 유사한 수준까지 도달하는 것 을 확인할 수 있다 ${ }^{16-24)}$.

\section{4. 서멧트 내 계면 형성 과정}

현재 서멧트는 탄/질화물 입자와 금속 성분이 혼합되 어 있는 혼합체에 대한 액상 소결 과정을 통해서 제조되 기 때문에 소결 온도에서 탄/질화물 입자들의 용해가 이 루어지고 냉각 중에 탄/질화물 입자의 재석출 및 결정화 가 일어나게 된다 ${ }^{25)}$. 만약 탄/질화물 입자가 여러 종류 가 아닌 한 가지 상으로만 이루어져 있다면 용해 및 재 석출에 의해 형성되는 입자는 단일상으로 존재하게 되 며 탄/질화물 입자가 여러 종류의 상들로 구성되어 있다 면 각 상들은 온도에 따른 안정성이 다르므로 액상에서 의 용해도 차이로 인하여 완전히 용해되지 않는 상이 있 을 수 있으며 용해된 성분들의 재석출은 용해되지 않은 입자 주변에서 이루어지게 되어 결국 코어-림 조직이 형성되게 된다. 타이타늄 탄/질화물계 서멧트는 물성의 보완 및 공정 개선을 위해 첨가되는 여러 종류의 금속 성분 및 탄화물로 코어-림 조직을 나타내며 코어-림 조 


\section{특 집 표 권한중}

직의 양상(코어-림 비율, 림 내 조성 등)에 따라서 서멧 트의 물성이 달라질 수 있으므로 타이타늄 탄/질화물계 서멧트에서 코어-림 조직 변화 과정과 조직을 제어하기 위한 공정 변수 관련 연구가 많이 수행되었다.

타이타늄 탄/질화물계 서멧트에 첨가되는 대표적인 성분은 텅스텐 탄화물(WC)이다. 텅스텐 탄화물은 타이 타늄 탄/질화물에 비해 인성이 우수하여 타이타늄 탄/ 질화물의 낮은 인성을 보완해줄 수 있고 타이타늄 탄/ 질화물과 금속 성분 간 낮은 적심성을 개선시킬 수 있 다. $1300{ }^{\circ} \mathrm{C}$ 에서 액상에서의 용해 속도는 텅스텐 탄화 물이 타이타늄 탄/질화물에 비해 약 5 배 높은데 이것은 열역학적 안정성이 텅스텐 탄화물이 타이타늄 탄/질화 물에 비해 낮기 때문이다. 2000년 Ahn et al.은 타이타 늄 탄/질화물계 서멧트에서 텅스텐 탄화물 첨가량과 타 이타늄 탄/질화물 내 질소량에 따른 미세조직 변화를 관 찰하고 코어-림 조직이 형성되는 과정과 림 조직의 조 성이 결정되는 요인에 대한 연구결과를 발표하였다 ${ }^{25)}$. 이 연구에서는 타이타늄 탄/질화물계 서멧트에서 미세 조직에 미치는 텅스텐 탄화물의 첨가량의 영향은 지극 히 제한적이라고 하였는데 이는 앞서 언급한 것처럼 텅 스텐 탄화물의 용해 속도가 타이타늄 탄/질화물의 용해 속도에 비해 훨씬 큰 이유로 림 조직 형성에 있어서 주 요한 인자가 되지 못하기 때문이다. 타이타늄 탄/질화물 내 질소량은 텅스텐 탄화물 첨가량과 달리 서멧트 미세 조직의 변화에 큰 영향을 미치는 것을 알게 되었는데 이 는 타이타늄 탄/질화물 상의 안정성이 질소량에 따라 달 라지고 안정성이 달라짐에 따라서 타이타늄 탄/질화물
의 용해 속도가 달라지기 때문이다. 즉, 타이타늄 탄/질 화물의 안정성은 텅스텐 탄화물에 비해 훨씬 높고 높은 안정성으로 인하여 액상 소결 시 액상으로의 용해 속도 가 낮아서 미세조직 변화에 큰 영향을 미치는 것이고 타 이타늄 탄/질화물의 안정성은 타이타늄 탄/질화물 내 질 소량에 따라 달라지므로 결과적으로 타이타늄 탄/질화 물 내 질소량은 서멧트 미세조직 변화의 주요 인자가 되 는 것이다.

\section{5. 서멧트 내 계면 감소를 위한 고용상 타이타늄 탄/질화물 상 안정성 연구}

앞서 소개한 것처럼 서멧트의 입자 강화 연구의 고용 된 형태의 타이타늄 탄/질화물 분말을 합성하고 서멧트 원료로 사용하는 것은 서멧트를 이루는 물질 고유 특성 을 향상시키는 것 이외에 미세조직에서 계면의 면적을 줄이는 것도 가능하게 한다. Fig. 4에서 알 수 있듯이 고용된 형태의 타이타늄 탄/질화물 분말을 원료로 사용 하면 타이타늄 탄/질화물계 서멧트의 미세조직 내 계면 면적은 작아지게 된다. 여러 종류의 탄/질화물이 혼합 된 혼합체를 서멧트 원료로 사용하지 않고 여러 성분들 이 고용되어 있는 단일 탄/질화물을 서멧트 원료로 사용 하면 Fig. 4의 오른쪽 Fig. 과 같은 미세조직을 얻을 수 있는데 이는 단일상의 경우 여러 원소들의 용해-재석 출 과정이 동시에 일어나 코어-림 조직이 형성되지 않 고 Fig. 4 왼쪽 Fig. 의 텅스텐 탄화물-코발트 소재와 유 사하게 단순한 조직이 만들어지게 된다. 서울대학교와 한국지질자원연구원 연구팀에 의해 여러 조성의 고용된
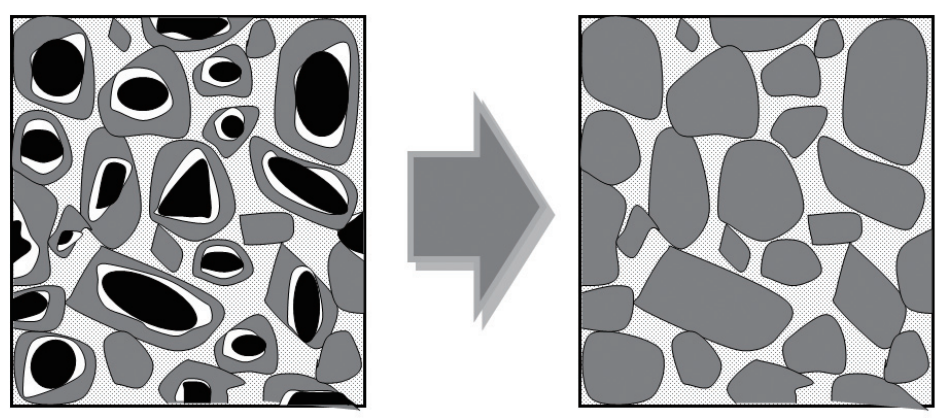

Fig. 4. Microstructure of solid solution type Ti based cermet 

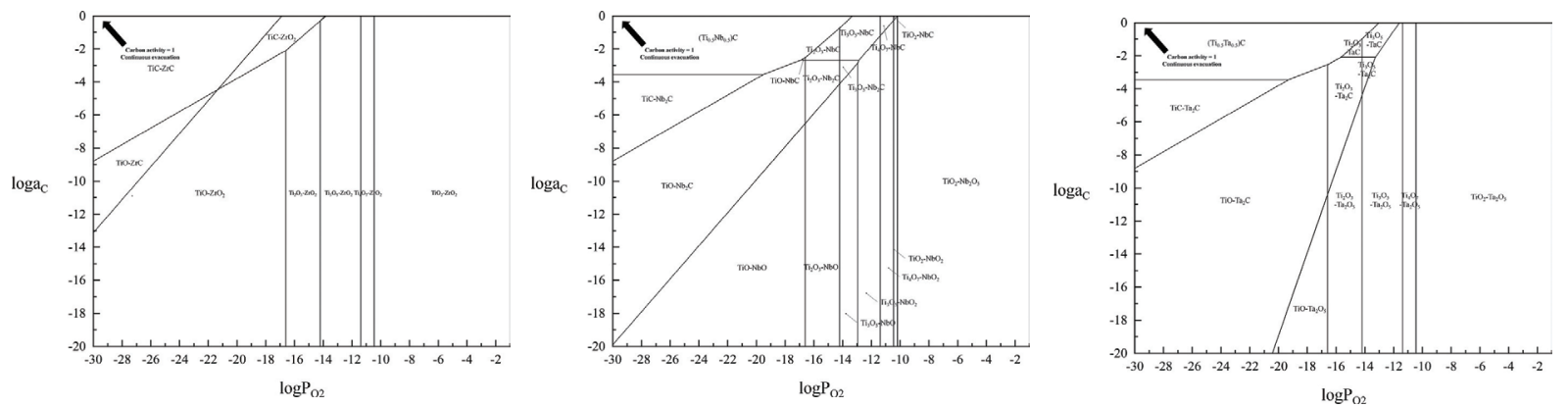

Fig. 5. Phase boundaries and domains in the Ti-M-C-O (M=Zr, Nb, and Ta) systems at $\left.1800 \mathrm{~K}^{27}\right)$

타이타늄 탄/질화물 합성 및 서멧트에 대한 적용 연구가 수행되어 왔는데 고용 원소에 따라 타이타늄 탄/질화물 격자 내 고용 한계가 다르며 타이타늄 탄/질화물 내 질 소량에 따라 고용 거동이 변화하게 되는 것을 상 안정성 관점에서 설명하였다 ${ }^{26-28)}$.

Fig. 5는 $\mathrm{Ti}-\mathrm{M}-\mathrm{C}-\mathrm{O}(\mathrm{Zr}, \mathrm{Nb}, \mathrm{Ta})$ 시스템에서 $\mathrm{Ti}$ 와 $\mathrm{M}$ 의 몰 비율이 $1: 1$ 인 경우에 대해 고용상인 $(\mathrm{Ti}, \mathrm{M}) \mathrm{C}$
가 형성되는 조건을 알 수 있는 상 안정성 다이어그램을 그린 것이다. $(\mathrm{Ti}, \mathrm{M}) \mathrm{C}$ 상에 대한 표준 생성 깁스 자유에 너지는 제 1 원리 계산을 통해 구하였고 나머지 산화물 및 탄화물 상에 대한 표준 생성 깁스 자유에너지는 문헌으 로부터 얻은 후 각 상들의 평형 조건을 아래와 같이 계 산하면 Fig. 5와 같이 상 안정성 다이어그램을 그릴 수 있다.

$$
\begin{aligned}
& 0.5 \mathrm{TiO}_{2}+0.5 \mathrm{NbO}_{x}+\mathrm{C}=\left(\mathrm{Ti}_{0.5} \mathrm{Nb}_{0.5}\right) \mathrm{C}+(0.5+0.25 x) \mathrm{O}_{2}, \\
& \Delta \mathrm{G}_{1800 \mathrm{~K}}^{\mathrm{f},\left(\mathrm{Ti}_{0.5} \mathrm{Nb}_{0.5}\right) \mathrm{C}}-0.5 \Delta \mathrm{G}_{1800 \mathrm{~K}}^{\mathrm{f}, \mathrm{TiO}_{2}}-0.5 \Delta \mathrm{G}_{1800 \mathrm{~K}}^{\mathrm{f}, \mathrm{NbO}_{x}}=-\mathrm{RT}\left(\ln \mathrm{P}_{\mathrm{O}_{2}}^{0.5+0.25 x}-\ln \mathrm{a}_{\mathrm{C}}\right) \\
& 0.125 \mathrm{Ti}_{4} \mathrm{O}_{7}+0.5 \mathrm{NbO}_{x}+\mathrm{C}=\left(\mathrm{Ti}_{0.5} \mathrm{Nb}_{0.5}\right) \mathrm{C}+(0.4375+0.25 x) \mathrm{O}_{2}, \\
& \Delta \mathrm{G}_{1800 \mathrm{~K}}^{\mathrm{f},\left(\mathrm{Ti}_{0.5} \mathrm{Nb}_{0.5}\right) \mathrm{C}}-0.125 \Delta \mathrm{G}_{1800 \mathrm{~K}}^{\mathrm{f}, \mathrm{Ti}_{4} \mathrm{O}_{7}}-0.5 \Delta \mathrm{G}_{1800 \mathrm{~K}}^{\mathrm{f}, \mathrm{NbO}_{x}}=-\mathrm{RT}\left(\ln \mathrm{P}_{\mathrm{O}_{2}}^{0.4375+0.25 x}-\ln \mathrm{a}_{\mathrm{C}}\right) \\
& 0.167 \mathrm{Ti}_{3} \mathrm{O}_{5}+0.5 \mathrm{NbO}_{x}+\mathrm{C}=\left(\mathrm{Ti}_{0.5} \mathrm{Nb}_{0.5}\right) \mathrm{C}+(0.4167+0.25 x) \mathrm{O}_{2}, \\
& \Delta \mathrm{G}_{1800 \mathrm{~K}}^{\mathrm{f},\left(\mathrm{Ti}_{0.5} \mathrm{Nb}_{0.5}\right) \mathrm{C}}-0.167 \Delta \mathrm{G}_{1800 \mathrm{~K}}^{\mathrm{f}, \mathrm{Ti}_{3} \mathrm{O}_{5}}-0.5 \Delta \mathrm{G}_{1800 \mathrm{~K}}^{\mathrm{f}, \mathrm{NbO}_{x}}=-\mathrm{RT}\left(\ln \mathrm{P}_{\mathrm{O}_{2}}^{0.4167+0.25 x}-\ln \mathrm{a}_{\mathrm{C}}\right) \\
& 0.25 \mathrm{Ti}_{2} \mathrm{O}_{3}+0.5 \mathrm{NbO}_{x}+\mathrm{C}=\left(\mathrm{Ti}_{0.5} \mathrm{Nb}_{0.5}\right) \mathrm{C}+(0.375+0.25 x) \mathrm{O}_{2}, \\
& \Delta \mathrm{G}_{1800 \mathrm{~K}}^{\mathrm{f},\left(\mathrm{Ti}_{0.5} \mathrm{Nb}_{0.5}\right) \mathrm{C}}-0.25 \Delta \mathrm{G}_{1800 \mathrm{~K}}^{\mathrm{f}, \mathrm{Ti}_{2} \mathrm{O}_{3}}-0.5 \Delta \mathrm{G}_{1800 \mathrm{~K}}^{\mathrm{f}, \mathrm{NbO}_{x}}=-\mathrm{RT}\left(\ln \mathrm{P}_{\mathrm{O}_{2}}^{0.375+0.25 x}-\ln _{\mathrm{C}}\right) \\
& 0.5 \mathrm{TiO}+0.5 \mathrm{NbO}_{x}+\mathrm{C}=\left(\mathrm{Ti}_{0.5} \mathrm{Nb}_{0.5}\right) \mathrm{C}+(0.25+0.25 x) \mathrm{O}_{2},
\end{aligned}
$$




$$
\begin{aligned}
& \Delta \mathrm{G}_{1800 \mathrm{~K}}^{\mathrm{f},\left(\mathrm{Ti}_{0.5} \mathrm{Nb}_{0.5}\right) \mathrm{C}}-0.5 \Delta \mathrm{G}_{1800 \mathrm{~K}}^{\mathrm{f}, \mathrm{TiO}}-0.5 \Delta \mathrm{G}_{1800 \mathrm{~K}}^{\mathrm{f}, \mathrm{NbO}}=-\mathrm{RT}\left(\operatorname{lnP}_{\mathrm{O}_{2}}^{0.25+0.25 x}-\ln \mathrm{C}_{\mathrm{C}}\right) \\
& 0.5 \mathrm{TiC}+0.5 \mathrm{NbO}_{x}+0.5 \mathrm{C}=\left(\mathrm{Ti}_{0.5} \mathrm{Nb}_{0.5}\right) \mathrm{C}+0.25 x \mathrm{O}_{2} \\
& \Delta \mathrm{G}_{1800 \mathrm{~K}}^{\mathrm{f},\left(\mathrm{Ti}_{0.5} \mathrm{Nb}_{0.5}\right) \mathrm{C}}-0.5 \Delta \mathrm{G}_{1800 \mathrm{~K}}^{\mathrm{f}, \mathrm{TiC}}-0.5 \Delta \mathrm{G}_{1800 \mathrm{~K}}^{\mathrm{f}, \mathrm{Nbo}_{x}}=-\mathrm{RT}\left(\ln _{\mathrm{O}_{2}}^{0.25 x}-\ln _{\mathrm{C}}^{0.5}\right) \\
& 0.5 \mathrm{TiC}+0.25 \mathrm{Nb}_{2} \mathrm{C}+0.25 \mathrm{C}=\left(\mathrm{Ti}_{0.5} \mathrm{Nb}_{0.5}\right) \mathrm{C}, \\
& \Delta \mathrm{G}_{1800 \mathrm{~K}}^{\mathrm{f},\left(\mathrm{Ti}_{0.5} \mathrm{Nb}_{0.5}\right) \mathrm{C}}-0.5 \Delta \mathrm{G}_{1800 \mathrm{~K}}^{\mathrm{f}, \mathrm{TiC}}-0.25 \Delta \mathrm{G}_{1800 \mathrm{~K}}^{\mathrm{f}, \mathrm{Nb}_{2} \mathrm{C}}=\mathrm{RTIna}_{\mathrm{C}}^{0.25} \\
& 0.5 \mathrm{TiO}_{2}+0.25 \mathrm{Ta}_{2} \mathrm{O}_{5}+\mathrm{C}=\left(\mathrm{Ti}_{0.5} \mathrm{Ta}_{0.5}\right) \mathrm{C}+1.125 \mathrm{O}_{2} \\
& \Delta \mathrm{G}_{1800 \mathrm{~K}}^{\mathrm{f},\left(\mathrm{Ti}_{0.5} \mathrm{Ta}_{0.5}\right) \mathrm{C}}-0.5 \Delta \mathrm{G}_{1800 \mathrm{~K}}^{\mathrm{f}, \mathrm{TiO}_{2}}-0.25 \Delta \mathrm{G}_{1800 \mathrm{~K}}^{\mathrm{f}, \mathrm{Ta}_{2} \mathrm{O}_{5}}=-\mathrm{RT}\left(\ln \mathrm{P}_{\mathrm{O}_{2}}^{1.125}-\ln \mathrm{C}_{\mathrm{C}}\right) \\
& 0.5 \mathrm{TiO}_{2}+0.25 \mathrm{Ta}_{2} \mathrm{C}+0.75 \mathrm{C}=\left(\mathrm{Ti}_{0.5} \mathrm{Ta}_{0.5}\right) \mathrm{C}+0.5 \mathrm{O}_{2}, \\
& \Delta \mathrm{G}_{1800 \mathrm{~K}}^{\mathrm{f},\left(\mathrm{Ti}_{0.5} \mathrm{Ta}_{0.5}\right) \mathrm{C}}-0.5 \Delta \mathrm{G}_{1800 \mathrm{~K}}^{\mathrm{f}, \mathrm{TiO}_{2}}-0.25 \Delta \mathrm{G}_{1800 \mathrm{~K}}^{\mathrm{f}, \mathrm{Ta}_{2} \mathrm{C}}=-\mathrm{RT}\left(\ln _{\mathrm{O}_{2}}^{0.5}-\ln \mathrm{a}_{\mathrm{C}}^{0.75}\right) \\
& 0.5 \mathrm{TiO}_{2}+0.5 \mathrm{TaC}+0.5 \mathrm{C}=\left(\mathrm{Ti}_{0.5} \mathrm{Ta}_{0.5}\right) \mathrm{C}+0.5 \mathrm{O}_{2}, \\
& \Delta \mathrm{G}_{1800 \mathrm{~K}}^{\mathrm{f},\left(\mathrm{Ti}_{0.5} \mathrm{Ta}_{0.5}\right) \mathrm{C}}-0.5 \Delta \mathrm{G}_{1800 \mathrm{~K}}^{\mathrm{f}, \mathrm{TiO}_{2}}-0.5 \Delta \mathrm{G}_{1800 \mathrm{~K}}^{\mathrm{f,TaC}}=-\mathrm{RT}\left(\ln _{\mathrm{O}_{2}}^{0.5}-\ln \mathrm{a}_{\mathrm{C}}^{0.5}\right) \\
& 0.125 \mathrm{Ti}_{4} \mathrm{O}_{7}+0.25 \mathrm{Ta}_{2} \mathrm{O}_{5}+\mathrm{C}=\left(\mathrm{Ti}_{0.5} \mathrm{Ta}_{0.5}\right) \mathrm{C}+1.0625 \mathrm{O}_{2} \\
& \Delta \mathrm{G}_{1800 \mathrm{~K}}^{\mathrm{f},\left(\mathrm{Ti}_{0.5} \mathrm{Ta}_{0.5}\right) \mathrm{C}}-0.125 \Delta \mathrm{G}_{1800 \mathrm{~K}}^{\mathrm{f}, \mathrm{Ti}_{4} \mathrm{O}_{7}}-0.25 \Delta \mathrm{G}_{1800 \mathrm{~K}}^{\mathrm{f}, \mathrm{Ta}_{2} \mathrm{O}_{5}}=-\mathrm{RT}\left(\ln \mathrm{P}_{\mathrm{O}_{2}}^{1.0625}-\ln \mathrm{C}_{\mathrm{C}}\right) \\
& 0.125 \mathrm{Ti}_{4} \mathrm{O}_{7}+0.25 \mathrm{Ta}_{2} \mathrm{C}+0.75 \mathrm{C}=\left(\mathrm{Ti}_{0.5} \mathrm{Ta}_{0.5}\right) \mathrm{C}+0.4375 \mathrm{O}_{2}, \\
& \Delta \mathrm{G}_{1800 \mathrm{~K}}^{\mathrm{f},\left(\mathrm{Ti}_{0.5} \mathrm{Ta}_{0.5}\right) \mathrm{C}}-0.125 \Delta \mathrm{G}_{1800 \mathrm{~K}}^{\mathrm{f}, \mathrm{Ti}_{4} \mathrm{O}_{7}}-0.25 \Delta \mathrm{G}_{1800 \mathrm{~K}}^{\mathrm{f}, \mathrm{Ta}_{2} \mathrm{C}}=-\mathrm{RT}\left(\operatorname{lnP}_{\mathrm{O}_{2}}^{0.4375}-\ln \mathrm{C}_{\mathrm{C}}^{0.75}\right) \\
& 0.125 \mathrm{Ti}_{4} \mathrm{O}_{7}+0.5 \mathrm{TaC}+0.5 \mathrm{C}=\left(\mathrm{Ti}_{0.5} \mathrm{Ta}_{0.5}\right) \mathrm{C}+0.4375 \mathrm{O}_{2}, \\
& \Delta \mathrm{G}_{1800 \mathrm{~K}}^{\mathrm{f},\left(\mathrm{Ti}_{0.5} \mathrm{Ta}_{0.5}\right) \mathrm{C}}-0.125 \Delta \mathrm{G}_{1800 \mathrm{~K}}^{\mathrm{f}, \mathrm{Ti}_{4} \mathrm{O}_{7}}-0.5 \Delta \mathrm{G}_{1800 \mathrm{~K}}^{\mathrm{f}, \mathrm{TaC}}=-\mathrm{RT}\left(\ln _{\mathrm{O}_{2}}^{0.4375}-\ln \mathrm{a}_{\mathrm{C}}^{0.5}\right) \\
& 0.167 \mathrm{Ti}_{3} \mathrm{O}_{5}+0.25 \mathrm{Ta}_{2} \mathrm{O}_{5}+\mathrm{C}=\left(\mathrm{Ti}_{0.5} \mathrm{Ta}_{0.5}\right) \mathrm{C}+1.042 \mathrm{O}_{2},
\end{aligned}
$$




$$
\begin{aligned}
& \Delta \mathrm{G}_{1800 \mathrm{~K}}^{\mathrm{f},\left(\mathrm{Ti}_{0.5} \mathrm{Ta}_{0.5}\right) \mathrm{C}}-0.167 \Delta \mathrm{G}_{1800 \mathrm{~K}}^{\mathrm{f}, \mathrm{Ti}_{3} \mathrm{O}_{5}}-0.25 \Delta \mathrm{G}_{1800 \mathrm{~K}}^{\mathrm{f}, \mathrm{Ta}_{2} \mathrm{O}_{5}}=-\mathrm{RT}\left(\ln \mathrm{P}_{\mathrm{O}_{2}}^{1.042}-\ln \mathrm{a}_{\mathrm{C}}\right) \\
& 0.167 \mathrm{Ti}_{3} \mathrm{O}_{5}+0.25 \mathrm{Ta}_{2} \mathrm{C}+0.75 \mathrm{C}=\left(\mathrm{Ti}_{0.5} \mathrm{Ta}_{0.5}\right) \mathrm{C}+0.4175 \mathrm{O}_{2}, \\
& \Delta \mathrm{G}_{1800 \mathrm{~K}}^{\mathrm{f},\left(\mathrm{Ti}_{0_{0.5}} \mathrm{Ta}_{0.5}\right) \mathrm{C}}-0.167 \Delta \mathrm{G}_{1800 \mathrm{~K}}^{\mathrm{f}, \mathrm{Ti}_{3} \mathrm{O}_{5}}-0.25 \Delta \mathrm{G}_{1800 \mathrm{~K}}^{\mathrm{f}, \mathrm{Ta}_{2} \mathrm{C}}=-\mathrm{RT}\left(\ln \mathrm{P}_{\mathrm{O}_{2}}^{0.4175}-\ln \mathrm{a}_{\mathrm{C}}^{0.75}\right) \\
& 0.167 \mathrm{Ti}_{3} \mathrm{O}_{5}+0.5 \mathrm{TaC}+0.5 \mathrm{C}=\left(\mathrm{Ti}_{0.5} \mathrm{Ta}_{0.5}\right) \mathrm{C}+0.4175 \mathrm{O}_{2} \\
& \Delta \mathrm{G}_{1800 \mathrm{~K}}^{\mathrm{f},\left(\mathrm{Ti}_{0.5} \mathrm{Ta}_{0.5}\right) \mathrm{C}}-0.167 \Delta \mathrm{G}_{1800 \mathrm{~K}}^{\mathrm{f,Ti} \mathrm{Ti}_{3} \mathrm{O}_{5}}-0.5 \Delta \mathrm{G}_{1800 \mathrm{~K}}^{\mathrm{f}, \mathrm{TaC}}=-\mathrm{RT}\left(\ln \mathrm{P}_{\mathrm{O}_{2}}^{0.4175}-\ln \mathrm{C}_{\mathrm{C}}^{0.5}\right) \\
& 0.25 \mathrm{Ti}_{2} \mathrm{O}_{3}+0.25 \mathrm{Ta}_{2} \mathrm{O}_{5}+\mathrm{C}=\left(\mathrm{Ti}_{0.5} \mathrm{Ta}_{0.5}\right) \mathrm{C}+\mathrm{O}_{2}, \\
& \Delta \mathrm{G}_{1800 \mathrm{~K}}^{\mathrm{f},\left(\mathrm{Ti}_{0.5} \mathrm{Ta}_{0.5}\right) \mathrm{C}}-0.25 \Delta \mathrm{G}_{1800 \mathrm{~K}}^{\mathrm{f}, \mathrm{Ti}_{2} \mathrm{O}_{3}}-0.25 \Delta \mathrm{G}_{1800 \mathrm{~K}}^{\mathrm{f}, \mathrm{Ta}_{2} \mathrm{O}_{5}}=-\mathrm{RT}\left(\ln \mathrm{P}_{\mathrm{O}_{2}}-\ln \mathrm{C}_{\mathrm{C}}\right) \\
& 0.25 \mathrm{Ti}_{2} \mathrm{O}_{3}+0.25 \mathrm{Ta}_{2} \mathrm{C}+0.75 \mathrm{C}=\left(\mathrm{Ti}_{0.5} \mathrm{Ta}_{0.5}\right) \mathrm{C}+0.375 \mathrm{O}_{2}, \\
& \Delta \mathrm{G}_{1800 \mathrm{~K}}^{\mathrm{f},\left(\mathrm{Ti}_{0.5} \mathrm{Ta}_{0.5}\right) \mathrm{C}}-0.25 \Delta \mathrm{G}_{1800 \mathrm{~K}}^{\mathrm{f}, \mathrm{Ti}_{2} \mathrm{O}_{3}}-0.25 \Delta \mathrm{G}_{1800 \mathrm{~K}}^{\mathrm{f}, \mathrm{Ta}_{2} \mathrm{C}}=-\mathrm{RT}\left(\ln \mathrm{P}_{\mathrm{O}_{2}}^{0.375}-\ln \mathrm{l}_{\mathrm{C}}^{0.75}\right) \\
& 0.25 \mathrm{Ti}_{2} \mathrm{O}_{3}+0.5 \mathrm{TaC}+0.5 \mathrm{C}=\left(\mathrm{Ti}_{0.5} \mathrm{Ta}_{0.5}\right) \mathrm{C}+0.375 \mathrm{O}_{2}, \\
& \Delta \mathrm{G}_{1800 \mathrm{~K}}^{\mathrm{f},\left(\mathrm{Ti}_{0.5} \mathrm{Ta}_{0.5}\right) \mathrm{C}}-0.25 \Delta \mathrm{G}_{1800 \mathrm{~K}}^{\mathrm{f}, \mathrm{Ti}_{2} \mathrm{O}_{3}}-0.5 \Delta \mathrm{G}_{1800 \mathrm{~K}}^{\mathrm{f}, \mathrm{TaC}}=-\mathrm{RT}\left(\operatorname{lnP}_{\mathrm{O}_{2}}^{0.375}-\ln \mathrm{a}_{\mathrm{C}}^{0.5}\right) \\
& 0.5 \mathrm{TiO}+0.25 \mathrm{Ta}_{2} \mathrm{O}_{5}+\mathrm{C}=\left(\mathrm{Ti}_{0.5} \mathrm{Ta}_{0.5}\right) \mathrm{C}+0.875 \mathrm{O}_{2} \\
& \Delta \mathrm{G}_{1800 \mathrm{~K}}^{\mathrm{f},\left(\mathrm{Ti}_{0.5} \mathrm{Ta}_{0.5}\right) \mathrm{C}}-0.5 \Delta \mathrm{G}_{1800 \mathrm{~K}}^{\mathrm{f}, \mathrm{TiO}}-0.25 \Delta \mathrm{G}_{1800 \mathrm{~K}}^{\mathrm{f}, \mathrm{Ta}_{2} \mathrm{O}_{5}}=-\mathrm{RT}\left(\ln \mathrm{P}_{\mathrm{O}_{2}}^{0.875}-\ln \mathrm{C}_{\mathrm{C}}\right) \\
& 0.5 \mathrm{TiO}+0.25 \mathrm{Ta}_{2} \mathrm{C}+0.75 \mathrm{C}=\left(\mathrm{Ti}_{0.5} \mathrm{Ta}_{0.5}\right) \mathrm{C}+0.25 \mathrm{O}_{2}, \\
& \Delta \mathrm{G}_{1800 \mathrm{~K}}^{\mathrm{f},\left(\mathrm{Ti}_{0.5} \mathrm{Ta}_{0.5}\right) \mathrm{C}}-0.5 \Delta \mathrm{G}_{1800 \mathrm{~K}}^{\mathrm{f}, \mathrm{TiO}}-0.25 \Delta \mathrm{G}_{1800 \mathrm{~K}}^{\mathrm{f}, \mathrm{Ta}_{2} \mathrm{C}}=-\mathrm{RT}\left(\operatorname{lnP}_{\mathrm{O}_{2}}^{0.25}-\ln \mathrm{a}_{\mathrm{C}}^{0.75}\right) \\
& 0.5 \mathrm{TiO}+0.5 \mathrm{TaC}+0.5 \mathrm{C}=\left(\mathrm{Ti}_{0.5} \mathrm{Ta}_{0.5}\right) \mathrm{C}+0.25 \mathrm{O}_{2} \\
& \Delta \mathrm{G}_{1800 \mathrm{~K}}^{\mathrm{f},\left(\mathrm{Ti}_{0.5} \mathrm{Ta}_{0.5}\right) \mathrm{C}}-0.5 \Delta \mathrm{G}_{1800 \mathrm{~K}}^{\mathrm{f}, \mathrm{TiO}}-0.5 \Delta \mathrm{G}_{1800 \mathrm{~K}}^{\mathrm{f}, \mathrm{TaC}}=-\mathrm{RT}\left(\ln _{\mathrm{O}_{2}}^{0.25}-\operatorname{lna}_{\mathrm{C}}^{0.5}\right) \\
& 0.5 \mathrm{TiC}+0.25 \mathrm{Ta}_{2} \mathrm{O}_{5}+0.5 \mathrm{C}=\left(\mathrm{Ti}_{0.5} \mathrm{Ta}_{0.5}\right) \mathrm{C}+0.625 \mathrm{O}_{2}, \\
& \Delta \mathrm{G}_{1800 \mathrm{~K}}^{\mathrm{f},\left(\mathrm{Ti}_{0.5} \mathrm{Ta}_{0.5}\right) \mathrm{C}}-0.5 \Delta \mathrm{G}_{1800 \mathrm{~K}}^{\mathrm{f}, \mathrm{TiC}}-0.25 \Delta \mathrm{G}_{1800 \mathrm{~K}}^{\mathrm{f}, \mathrm{Ta}_{2} \mathrm{O}_{5}}=-\mathrm{RT}\left(\ln \mathrm{P}_{\mathrm{O}_{2}}^{0.625}-\ln \mathrm{C}_{\mathrm{C}}^{0.5}\right)
\end{aligned}
$$




$$
\begin{gathered}
0.5 \mathrm{TiC}+0.25 \mathrm{Ta}_{2} \mathrm{C}+0.25 \mathrm{C}=\left(\mathrm{Ti}_{0.5} \mathrm{Ta}_{0.5}\right) \mathrm{C}, \\
\Delta \mathrm{G}_{1800 \mathrm{~K}}^{\mathrm{f},\left(\mathrm{Ti}_{0.5} \mathrm{Ta}_{0.5}\right) \mathrm{C}}-0.5 \Delta \mathrm{G}_{1800 \mathrm{~K}}^{\mathrm{f}, \mathrm{TiC}}-0.25 \Delta \mathrm{G}_{1800 \mathrm{~K}}^{\mathrm{f}, \mathrm{Ta}_{2} \mathrm{C}}=\mathrm{RT} \operatorname{lna}_{\mathrm{C}}^{0.25}
\end{gathered}
$$

표 3은 제 1 원리 계산을 통해 구한 고용상의 표준 생성 깁스 자유에너지이며 이 표를 통해서 $\mathrm{Zr}$ 이 고용된 고용 상의 경우 혼합상에 비해 불안정하여 Fig. 5 에서 확인할 수 있듯이 상 안정성 다이어그램 상 $(\mathrm{Ti}, \mathrm{Zr}) \mathrm{C}$ 상은 존재 하지 않음을 알 수 있다. Fig. 5 를 통해서 산화물에 대한 탄화환원 과정을 통해 고용상을 제조할 때 공정 조건을 확인할 수 있다.

\section{6. 서멧트 내 계면 강화 연구}

서멧트의 파괴 양상은 앞서 언급한 것처럼 입내 파괴 와 입계 파괴가 구분되고 탄/질화물 입자와 금속 성분이 공존하는 서멧트에서 계면은 탄/질화물 성분과 금속 성 분 간 계면이므로 일반 세라믹스 소결체에서의 계면과 비교하여 정합성이 낮아 파괴에 취약한 부분이 될 수 있 다. 특히, 타이타늄 탄/질화물은 타이타늄의 높은 산소 친화도로 인해 타이타늄 탄/질화물 입자 표면에 산화물 층이 형성되기 쉽고 표면에 존재하는 산화물 층은 타이 타늄 탄/질화물을 원료로 제조되는 서멧트 내 미세조직 에서 탄/질화물 입자와 금속 간 계면에서의 정합성을 약 화시키는 이유가 될 수 있다. 이에 따라 서멧트 내 탄/질 화물 입자와 금속 간 계면의 정합성 향상을 위한 연구가 수행되어 왔으며 계면에서의 산화물 층 제거 및 구조 개
선을 위한 방법이 고안되었다.

\section{7. 서멧트 내 계면 정합성 향상을 위한 복합 분말 합성 연구}

기존 서멧트는 탄/질화물 원료와 금속 성분에 대한 혼 합 과정을 거쳐 탄/질화물/금속 혼합 분말을 얻고 이 혼 합 분말에 대한 액상 소결을 통해 제조된다. 원료 분말 은 진공이나 비활성 분위기에서 보관 및 이동이 되지 않 기 때문에 표면에 산화층이 형성된 상태이며 이러한 분 말을 사용하여 서멧트를 제조하면 계면에서 산소 농도 가 높아지고 계면 정합성이 낮아질 가능성이 있다. 이러 한 계면에서의 산소 영향을 줄이고 계면 정합성을 높이 기 위한 방법으로 탄/질화물-금속 복합 분말 합성 및 이 를 활용하여 서멧트를 제조하는 방법이 있다. 즉, 탄/질 화물 입자와 금속 성분이 복합화된 탄/질화물-금속 분 말을 합성하고 이를 소결하는 것인데 복합화된 분말은 탄/질화물 입자와 금속 성분을 동시에 합성하기 때문에 분말 상태에서 탄/질화물 입자와 금속 성분은 접한 상태 로 존재하게 된다. 탄/질화물 입자와 금속 성분이 접한 상태로 존재하기 때문에 타이타늄 탄/질화물의 경우 표 면 산화 정도가 덜할 것임을 예상할 수 있다. 액상 소결 과정에서는 탄/질화물 입자들은 액상 출현 온도에서 용

Table 3. Standard Gibbs free energy of formation of $\left(\mathrm{Ti}_{0.5} \mathrm{M}_{0.5}\right) \mathrm{C}(\mathrm{M}=\mathrm{Zr} \text {, Nb, and Ta) at } 1800 \mathrm{~K} \text { (unit: } \mathrm{kJ} / \mathrm{mole})^{27-28)}$

\begin{tabular}{c|c|c|c}
\hline \multirow{2}{*}{} & \multicolumn{2}{|c|}{ M } & Nb \\
\cline { 2 - 4 } & Zr & -132.578 & -140.482 \\
\hline Monocarbide & -181.441 & -154.703 & -162.837 \\
\hline$\left(\mathrm{Ti}_{0.5} \mathrm{M}_{0.5}\right) \mathrm{C}$ & -144.875 & -132.578 & -140.482 \\
\hline
\end{tabular}


해 및 재석출 과정을 겪게 되고 냉각 중 금속 성분은 재 석출된 탄/질화물 입자와 계면을 형성하게 된다. 이 때 대부분의 소결 과정에서 형성되는 탄/질화물 입자와 금 속 성분 간 계면은 정합성이 낮게 된다. 하지만 복합 분 말의 경우 탄/질화물 입자와 금속 성분 간 계면은 이미 형성되어 있고 이 계면은 분말 합성 과정에서 탄/질화물 과 금속 상이 형성되면서 생성된 것이므로 정합성이 높 을 가능성이 크다. 이 계면을 유지하면서 소결 과정을 거치게 된다면 즉, 용해-재석출 과정을 거치지 않고 복 합 분말 내 계면을 유지한 상태에서 치밀화된 소결체를 얻을 수 있다면 정합성이 높은 계면이 포함된 서멧트를 제조할 수 있다. 소결 과정 중 용해-재석출 과정이 없도 록 하기 위해서는 액상 출현이 없고 용해 및 재석출 과 정을 위한 시간이 부족해야 하므로 가압 및 급속 소결 공정이 필요하다.

2013년 X. Song et al.은 텅스텐 산화물, 코발트 산 화물 및 카본블랙을 밀링을 통해 혼합 및 분쇄한 후 열 처리하여 텅스텐 탄화물-코발트 복합 분말을 합성하였 다 ${ }^{29-30)}$. 합성된 분말에 대한 추가적인 밀링 과정을 통해 약 $65 \mathrm{~nm}$ 크기의 나노 복합 분말이 얻어졌고 나노 복합 분말은 방전 플라즈마 소결법에 의하여 소결체로 제조 되었다. 제조된 소결체의 파괴인성은 $14.5 \mathrm{MPa} \cdot \mathrm{m}^{1 / 2}$ 으 로 높은 값을 나타내었는데 경도가 $20.5 \mathrm{GPa}$ 로 우수한 것을 감안하면 이 소결체의 기계적 물성은 매우 뛰어나 다고 할 수 있다. 표 1 의 기존 텅스텐 탄화물-코발트 서 멧트의 기계적 물성에서 알 수 있듯이 텅스텐 탄화물코발트 소결체의 파괴인성이 $14 \sim 16 \mathrm{MPa} \cdot \mathrm{m}^{1 / 2}$ 인 경우 기존 소결체는 경도가 12 13 $\mathrm{GPa}$ 수준으로 낮아지게 된다. 반면 텅스텐 탄화물-코발트 소결체의 경도가 18 $\mathrm{GPa}$ 이상이 되게 되면 텅스텐 탄화물-코발트 소결체 의 파괴인성은 $10 \mathrm{MPa} \cdot \mathrm{m}^{1 / 2}$ 미만으로 저하되게 된다. 즉, 서멧트의 경도 및 파괴인성은 서로 트레이드 오프의 관계를 갖고 있어 두 가지 물성을 모두 우수한 서멧트를 얻는 것은 불가능하였다. 서멧트에서 경도는 탄/질화물 입자의 사이즈에 반비례하여 입자 사이즈가 작아질수록 경도는 증가하게 된다. 반면, 입자 사이즈가 작아지게 되면 탄/질화물 입자와 금속 성분이 이루고 있는 계면
의 면적은 넓어지게 되어 파괴에 취약한 영역이 커지게 되어 파괴인성은 낮아지게 된다. 이러한 이유로 나노 입 자가 분포되어 있는 서멧트의 경우 경도는 우수하여 내 마모 부품용 소재로 사용할 때 품질 향상에 효과적일 수 있다. 하지만 나노 입자가 분포되어 있는 서멧트의 파 괴인성은 기존 마이크론 사이즈 입자가 분포된 서멧트 와 비교하여 낮기 때문에 절삭공구 소재로 사용되면 파 괴에 취약해져 공구 수명이 짧아질 수 있다. X. Song et al. 의 연구에서는 나노 사이즈 텅스텐 탄화물 입자가 분 포되어 있는 텅스텐 탄화물-코발트 서멧트의 파괴인성 을 향상시키기 위해 계면 구조를 개선하였다. 즉, 텅스 텐 탄화물의 입자 사이즈가 나노 사이즈로 작아지면서 계면 면적의 확대는 피할 수 없지만 계면 구조를 개선하 고 계면 특성을 향상시켜 파괴인성 저하를 방지하였다. 텅스텐 탄화물-코발트 서멧트 내 계면은 일반적인 액상 소결을 통해 제조된다면 텅스텐 탄화물이 액상 코발트 에 용해된 후 냉각 시 석출되면서 만들어지게 되며 이렇 게 만들어지는 계면의 경우 정합성이 양호한 계면이 될 가능성이 적다. 정합성이 우수한 계면이 포함된 텅스텐 탄화물-코발트 서멧트를 제조하기 위하여 텅스텐 탄화 물-코발트 복합 분말을 합성하고 이에 대한 급속 소결 을 진행하였으며 이는 텅스텐 탄화물과 코발트를 동시 에 합성하고 급속 소결하여 계면 구조가 소결 과정을 통 해 변화되는 것을 방지하기 위한 것이었다.

$\mathrm{X}$. Song et al. 의 연구에서 계면 구조 개선을 위해 적 용한 급속 소결법인 방전 플라즈마 소결법은 배치 당 제 조 가능한 제품이 적고 제품 크기에도 한계가 있어 상용 공정에는 활용이 어려운 소결법이다. 상압 소결 방법이 가장 기술 상용화에 적합한 공정이며 2014년 H. Kwon et al.은 탄/질화물-금속 복합 분말에 대한 단시간의 상 압 소결법 적용을 통해 계면 구조가 개선된 서멧트를 제 조하는 방법을 제시하였다 ${ }^{31-34)}$. 이 연구에서는 타이타 늄 합금( $\mathrm{Ti}-\mathrm{Ni}, \mathrm{Ti}-\mathrm{Co}$ 합금)과 탄소를 고에너지 밀링을 통해 반응시켜 복합 분말을 합성하게 된다.

$\mathrm{Ti}-\mathrm{Ni}(\mathrm{s})$ or $\mathrm{Ti}-\mathrm{Co}(\mathrm{s})+\mathrm{C}(\mathrm{s}) \rightarrow \mathrm{TiC}-\mathrm{Ni}(\mathrm{s})$ or $\mathrm{TiC}-$ $\mathrm{Co}(\mathrm{s})$

니켈과 코발트가 포함되어 있는 타이타늄 합금과 탄 
Table 4. Standard Gibbs free energies of formation and lattice parameters of $\left(\mathrm{TiNi}_{x} \mathrm{Ni}_{-\mathrm{x}}\right) \mathrm{C}(\mathrm{x}=1,0.75,0.5$ and 0$)$, obtained through firstprinciples calculations31)

\begin{tabular}{|c|c|c|c|c|c|c|}
\hline & \multirow{2}{*}{$\begin{array}{l}\text { Temperature } \\
\text { (K) }\end{array}$} & \multicolumn{5}{|c|}{$\mathrm{x}$ in $\left(\mathrm{Ti}_{\mathrm{x}} \mathrm{Ni}_{1-\mathrm{x}}\right) \mathrm{C}$} \\
\hline & & 1 & 0.75 & 0.5 & 0.25 & 0 \\
\hline Lattice parameter $(\AA)$ & 298.15 & 4.318 & 4.249 & 4.172 & 4.101 & 4.06 \\
\hline \multirow{4}{*}{$\Delta \mathrm{G}_{\mathrm{T},\left(\mathrm{Ti}_{x} \mathrm{Ni}_{1-x}\right) \mathrm{C}}^{\circ}$} & 298.15 & -180.53 & -78.74 & 9.97 & 99.48 & 194.80 \\
\hline & 1000 & -173.40 & -69.08 & 24.51 & 117.80 & 216.66 \\
\hline & 1500 & -165.90 & -60.06 & 37.83 & 134.55 & 236.29 \\
\hline & 2000 & -157.77 & -50.46 & 52.56 & 153.26 & 259.00 \\
\hline \multirow{4}{*}{$x \cdot \Delta \mathrm{G}_{\mathrm{T}, \mathrm{TiC}}^{\circ}-\Delta \mathrm{G}_{\mathrm{T},\left(\mathrm{Ti}_{x} \mathrm{Ni}_{1-x}\right) \mathrm{C}}^{\circ}$} & 298.15 & 0 & -56.66 & -100.24 & -144.61 & -194.80 \\
\hline & 1000 & 0 & -60.97 & -111.21 & -161.15 & -216.66 \\
\hline & 1500 & 0 & -64.37 & -120.78 & -176.03 & -236.29 \\
\hline & 2000 & 0 & -67.87 & -131.45 & -192.70 & -259.00 \\
\hline
\end{tabular}

소를 반응시키면 타이타늄과 탄소의 높은 친화도로 인 해 타이타늄 탄/질화물과 금속 니켈, 코발트가 혼합되어 있는 복합 분말이 합성이 된다. 표 4는 타이타늄 탄/질 화물 격자 내 $\mathrm{Ni}$ 의 고용에 따른 탄/질화물 상의 표준 생 성 깁스 자유에너지를 제 1 원리 계산을 통해 구한 것으로 $\mathrm{Ni}$ 이 고용되지 않은 순수 $\mathrm{TiC}$ 와 고용된 상의 안정성을 비교하면 조성과 온도에 관계없이 순수 $\mathrm{TiC}$ 가 안정한 것을 알 수 있어 $\mathrm{Ti}-\mathrm{Ni}$ 합금을 탄소와 반응시키면 $\mathrm{TiC}-$ $\mathrm{Ni}$ 복합 분말이 형성될 것이라 예측할 수 있다. 또한, 복 합 분말 내 $\mathrm{TiC}$ 와 $\mathrm{Ni}$ 상이 동일한 전구체로부터 형성되

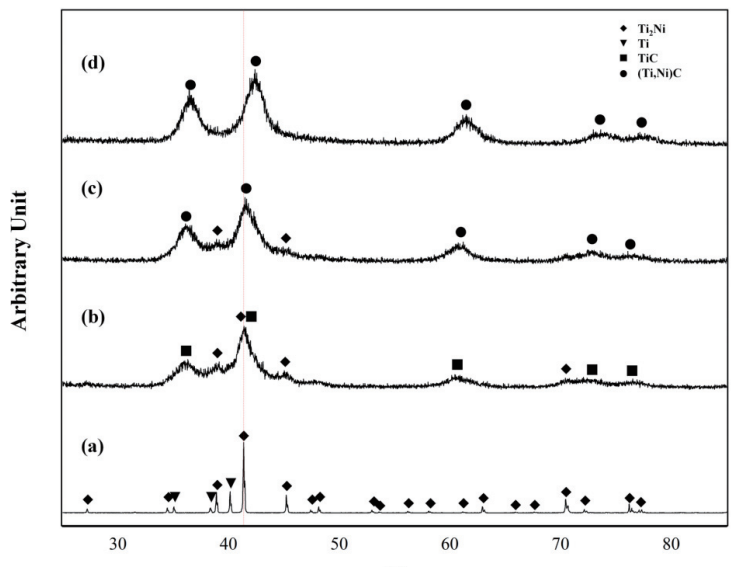

$2 \theta$

Fig. 6. XRD profiles for (a) the Ti-Ni raw material and the Ti-Ni and graphite powders milled for (b) 5, (c) 10, and (d) 20 $\mathrm{h}^{31)}$
기 때문에 $\mathrm{TiC}$ 와 $\mathrm{Ni}$ 이 이루는 계면의 정합성은 양호할 것으로 예상할 수 있다. Fig. 6는 복합 분말 합성에 사용 된 합금 및 반응 후 합성된 복합 분말의 상을 분석한 것 으로 반응 시간(밀링 시간)이 증가할수록 합금 상이 사 라지고 $\mathrm{TiC}$ 상만 존재하게 되는 것을 알 수 있다. 합성 된 상은 데이터베이스의 $\mathrm{TiC}$ 와 패턴은 같으나 피크의 위치는 이동되어 있는 것을 확인할 수 있는데 이는 $\mathrm{TiC}$ 격자로의 $\mathrm{Ni}$ 고용이 원인인 것으로 보인다. $\mathrm{Ni}$ 의 원자 반경이 $\mathrm{Ti}$ 의 원자 반경에 비해 작아 $\mathrm{TiC}$ 내 $\mathrm{Ni}$ 고용으로 인하여 피크의 이동이 나타난 것이다. 표 4 의 $(\mathrm{Ti}, \mathrm{Ni}) \mathrm{C}$

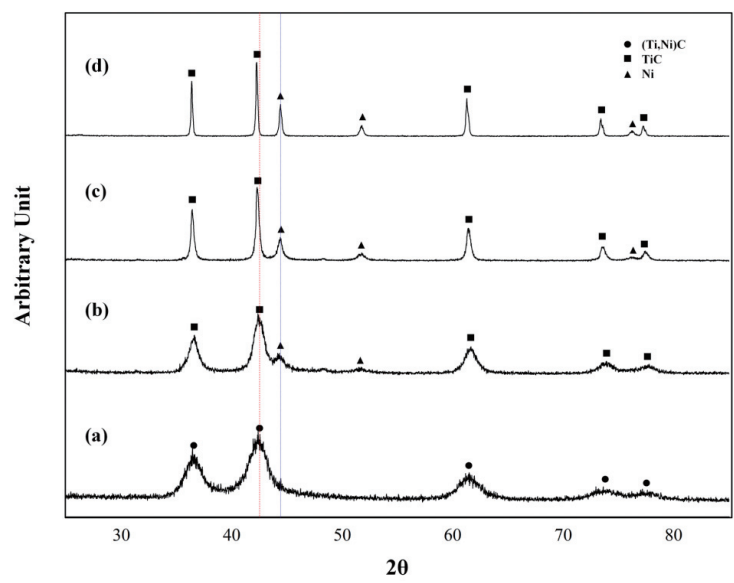

Fig. 7. XRD profiles for (a) the synthesized (Ti,Ni)C powder and the (Ti,Ni)C powder heat treated for $2 \mathrm{~h}$ at (b) 900, (c) 1100 , and $(d) 1200{ }^{\circ} \mathrm{C}^{31)}$ 

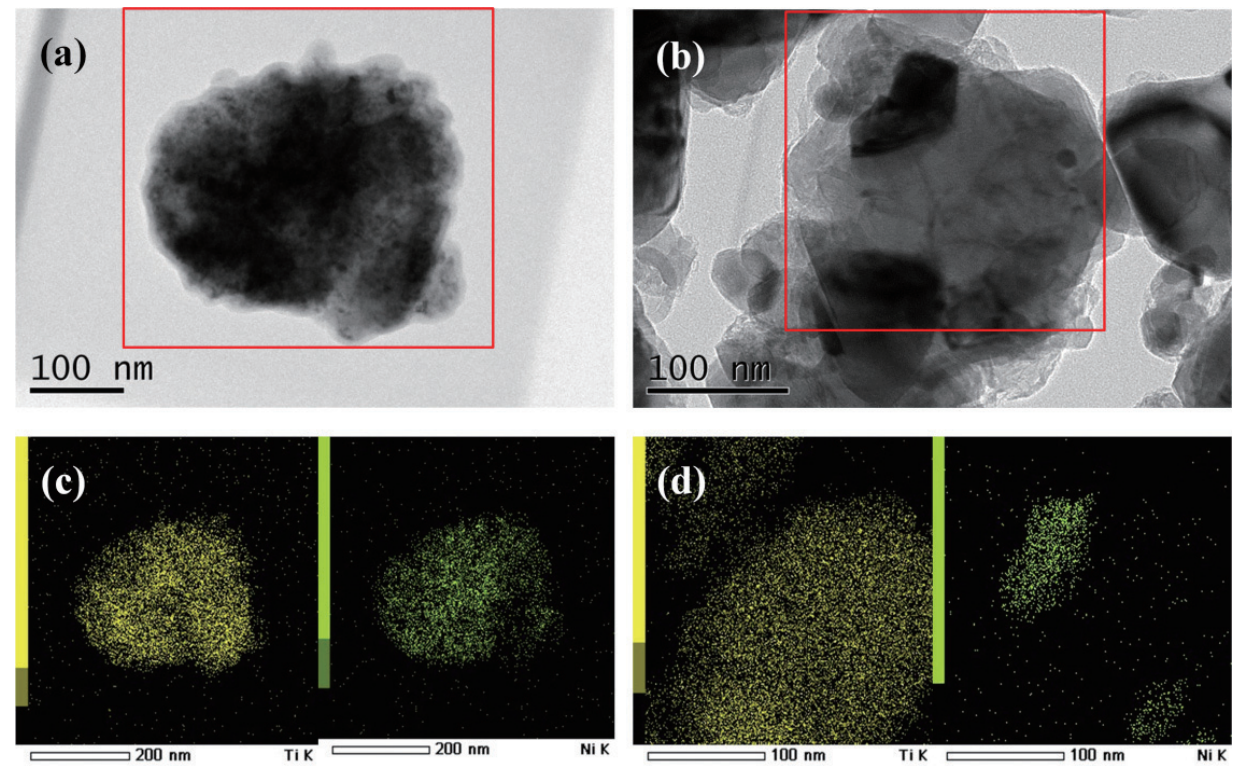

Fig. 8. TEM micrographs of (a) the (Ti,Ni)C powder milled for $20 \mathrm{~h}$ and (b) the (Ti,Ni)C powder heat treated at $1200{ }^{\circ} \mathrm{C}$ for $2 \mathrm{~h}$. Also shown are the EDS maps of $(\mathrm{c})$ the $(\mathrm{Ti}, \mathrm{Ni}) \mathrm{C}$ powder and $(\mathrm{d})$ the $(\mathrm{Ti}, \mathrm{Ni}) \mathrm{C}$ powder heat treated at $1200{ }^{\circ} \mathrm{C}$ for $2 \mathrm{~h}^{31)}$

상의 불안정성을 고려하면 합성된 $(\mathrm{Ti}, \mathrm{Ni}) \mathrm{C}$ 는 준 안정상 인 것으로 생각되며 이는 Fig. 7의 열처리를 통한 상 분 리 결과를 통해 확실히 알 수 있다. Fig. 8은 밀링을 통 해 합성된 분말의 형상의 TEM으로 관찰한 것으로 결정 립은 $100 \mathrm{~nm}$ 미만인 것을 알 수 있으며 $\mathrm{Ti}$ 와 $\mathrm{Ni}$ 의 분포 는 나노 단위에서 균일한 것을 알 수 있다. 밀링으로 합 성된 분말에 대한 열처리 과정을 통해 $\mathrm{TiC}$ 와 $\mathrm{Ni}$ 의 결정 화가 이루어지는 것을 알 수 있는데 $\mathrm{TiC}$ 와 $\mathrm{Ni}$ 의 결정화 가 동시에 이루어지기 때문에 $\mathrm{TiC}$ 와 $\mathrm{Ni}$ 의 계면은 정합 성이 우수할 것이라 사료되었다.

밀링 과정에서 타이타늄 합금과 탄소의 반응으로 합 성된 복합 분말 내 결정립의 사이즈는 Fig. 8에서 알 수 있듯이 $10 \mathrm{~nm}$ 수준으로 미세한 것을 알 수 있고 복합 분 말 내 $\mathrm{Ni}$ 의 상태는 결정성이 매우 낮기 때문에 소결에 대한 구동력은 기존 혼합체에 비해 월등히 높을 것이라 예상할 수 있다. Fig. 9는 밀링을 통해 합성된 TiC-Ni 복합 분말에 대한 온도에 따른 열 출입을 조사한 것으로 비교하기 위해 제시되는 기존 혼합 분말은 니켈 성분의 용해로 인한 피크만이 존재하는데 비해 합성된 복합 분 말의 경우 밀링으로 혼입된 산소의 탄화 반응, 결정화,
니켈의 용해에 해당되는 피크가 발견되었다. 니켈의 용 해 온도는 복합 분말에서 낮아지는 것을 알 수 있는데 복합 분말 내 니켈의 결정성이 낮은 것이 원인으로 사료 되었고 이에 따라 복합 분말의 소결 온도는 기존 혼합체 의 소결 온도에 비해 낮을 것으로 예상할 수 있다. 복합 분말의 사이즈와 니켈의 용해 온도를 감안하면 복합 분 말은 저온에서 짧은 시간동안 소결을 통해 완전 치밀화

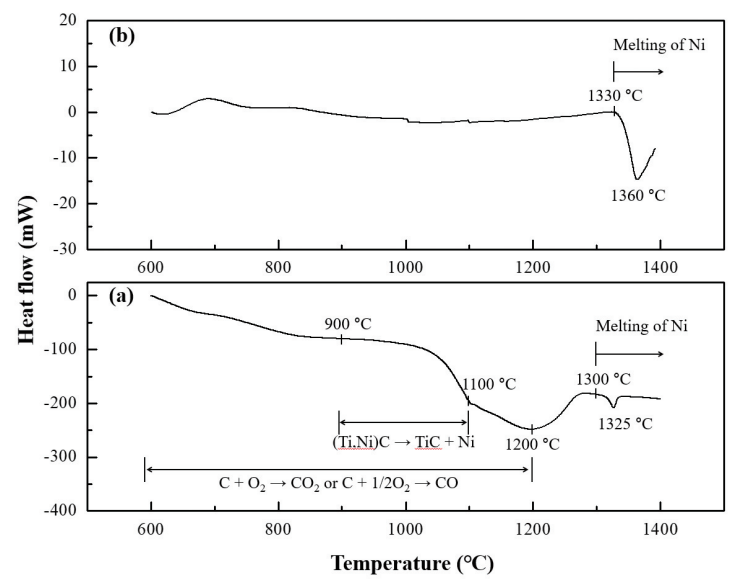

Fig. 9. DSC curves for (a) (Ti,Ni)C and (b) conventional Ti(CN)Ni powders ${ }^{32}$ 


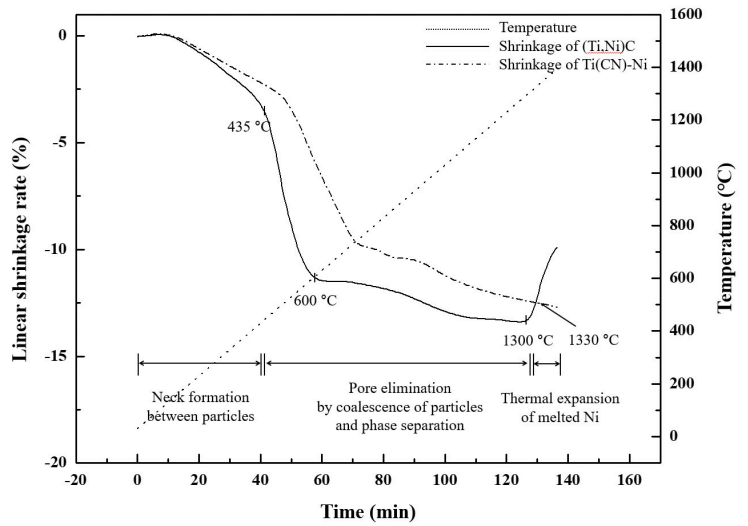

Fig. 10. Linear shrinkage rates of $(\mathrm{Ti}, \mathrm{Ni}) \mathrm{C}$ and $\mathrm{Ti}(\mathrm{CN})-\mathrm{Ni}$ compacts $^{32}$

된 소결체를 얻는 것이 가능할 것으로 판단되었다.

Fig. 10은 온도에 따른 수축율을 측정한 것으로 기 존 혼합 분말은 $1500{ }^{\circ} \mathrm{C}$ 까지 수축이 완료되지 않는 반 면 복합 분말의 경우 $1300{ }^{\circ} \mathrm{C}$ 에서 수축이 완료되는 것 을 알 수 있다. 따라서 복합 분말은 $1300{ }^{\circ} \mathrm{C}$ 이상의 온
도에서 소결 시 완전한 소결체 제조가 가능할 것으로 생 각할 수 있다. Fig. 11 은 $1300{ }^{\circ} \mathrm{C}$ 내외의 온도에서 짧은 시간(5분)동안 소결한 후 소결체의 미세조직을 관찰한 것으로 복합 분말의 경우 $1330{ }^{\circ} \mathrm{C}$ 에서 소결한 경우 기 공이 없는 완전 치밀화된 소결체가 얻어졌으며 반면 기 존 혼합 분말은 채워지지 않은 기공이 관찰된다. 즉, 타 이타늄 합금과 탄소의 반응으로 합성된 나노 복합 분말 은 기존 서멧트 소결 온도 $\left(1500{ }^{\circ} \mathrm{C}\right)$ 에 비해 낮은 온도인 $1330{ }^{\circ} \mathrm{C}$ 에서 단 5 분의 소결만으로 완전 치밀화가 가능 한 것이다. $1330{ }^{\circ} \mathrm{C}$ 는 Fig. 9 의 열 분석 결과에서 알 수 있는 액상 출현 온도 근처의 온도이지만 유지 시간은 단 5 분에 불과하기 때문에 $\mathrm{TiC}$ 의 용해-재석출 과정을 위 한 시간은 충분하지 않을 것으로 생각되며 복합 분말 상 태에서 만들어진 정합성이 양호한 계면이 상당 부분 유 지될 것으로 예상된다. 이러한 이유로 소결체 내 $\mathrm{TiC}$ 와 $\mathrm{Ni}$ 이 이루는 계면은 정합성이 양호할 것으로 보이며 이 러한 점은 소결체의 파괴인성에 도움이 될 것으로 사료 된다. Fig. 12는 저온 및 단시간 소결 후 소결체의 상대
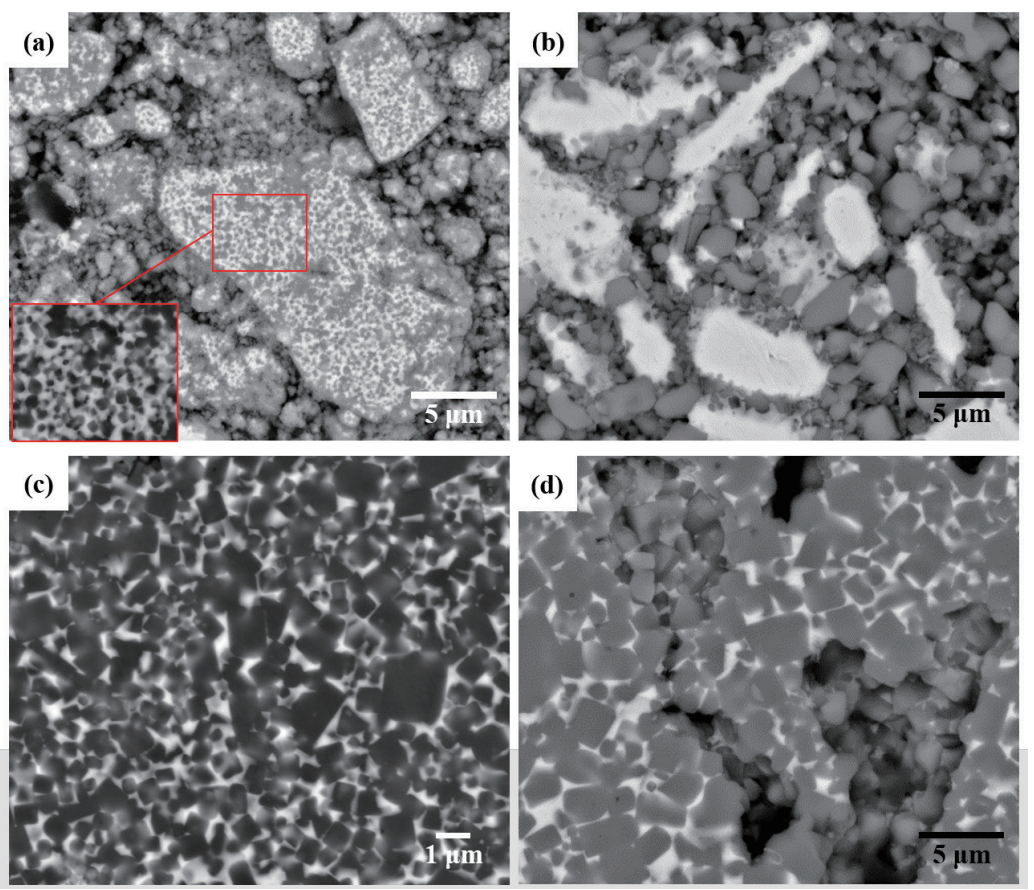

Fig. 11. FE-SEM micrographs of (a) (Ti,Ni)C and (b) Ti(CN)-Ni sintered at $1250{ }^{\circ} \mathrm{C}$ for 5 min, (c) (Ti,Ni)C and (d) Ti(CN)-Ni sintered at $1330{ }^{\circ} \mathrm{C}$ for $5 \mathrm{~min}^{32}$ 


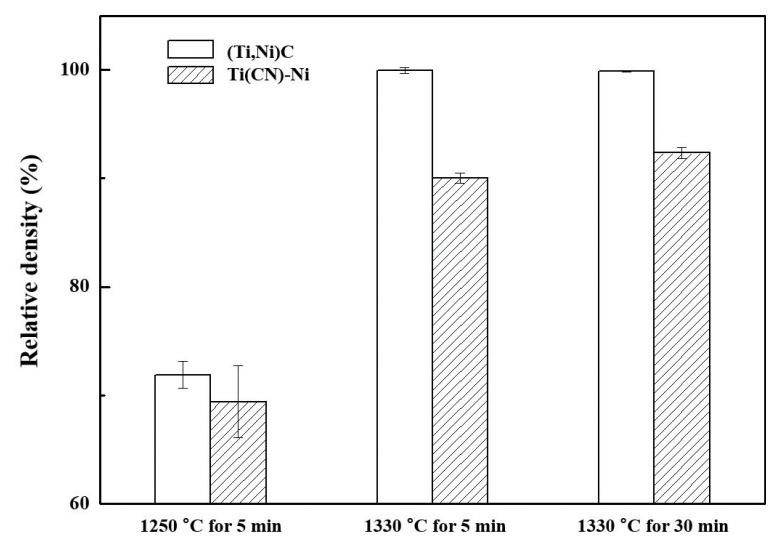

Fig. 12. Relative densities of (Ti,Ni)C and $\mathrm{Ti}(\mathrm{CN})-\mathrm{Ni}$ after sintering ${ }^{32}$

밀도를 측정한 결과를 나타내며 복합 분말의 경우 1330 ${ }^{\circ} \mathrm{C}$ 에서 5 분 동안의 소결 후 상대밀도 $99 \%$ 이상의 소결 체가 얻어졌으며 소결 시간을 30 분으로 증가시켜도 상 대밀도의 값은 차이가 없는 것을 알 수 있어 5 분의 소결 시간에 완전 치밀화된 소결체가 제조될 수 있음을 알 수 있다. 복합 분말에 대한 저온 및 단시간 소결을 통해 제 조된 TiC-Ni 소결체는 물성 평가 시 경도는 $13.6 \mathrm{GPa}$, $10.1 \mathrm{MPa} \cdot \mathrm{m}^{1 / 2}$ 로 표 1 에 나타낸 기존 $\mathrm{TiC}-\mathrm{Ni}$ 서멧트 에 비해 우수한 것을 알 수 있으며 텅스텐 탄화물이 첨 가된 서멧트에 비해서도 파괴인성 면에서 우위에 있는 것을 확인할 수 있다. 이는 낮은 온도에서 짧은 시간동 안 소결을 진행하여 용해-재석출에 의한 불완전한 계면 형성이 억제되고 기존 복합 분말에서 형성되어 있던 정 합성이 양호한 계면이 유지되었기 때문으로 사료된다.

\section{3. 결론}

세라믹 금속 복합 재료 중 탄/질화물과 금속 성분으 로 이루어진 서멧트는 우수한 기계적 물성으로 절삭공 구, 내마모성 부품(압연 롤, 금형 등)의 소재로 사용되고 있다. 공구 및 초경 부품의 수명은 소재의 물성 중 파괴 인성에 관련이 되어 있으며 파괴인성은 파괴에 대한 저 항성을 나타내는 지표로 소재의 파괴는 미세조직 상 입
자의 균열 혹은 입계의 균열에 의해 일어나게 된다. 특 히 서멧트 중 타이타늄 탄/질화물계 서멧트의 경우 여러 첨가 원소 혹은 탄/질화물이 혼합되는 관계로 미세조직 상 코어-림 조직이 형성되어 계면의 면적이 텅스텐 탄 화물계 서멧트에 비해 넓은 것이 특징으로 넓은 계면 면 적은 타이타늄 탄/질화물의 자체적인 낮은 인성에 더불 어 타이타늄 탄/질화물계 서멧트의 파괴인성이 텅스텐 탄화물계 소재에 비해 열세인 원인이 된다. 고용상 형태 의 타이타늄 탄/질화물의 적용을 통한 계면 면적의 감소 와 나노 사이즈의 탄/질화물-금속 복합 분말에 대한 저 온 및 단시간 소결을 통한 계면 강화(정합성 향상)는 타 이타늄 탄/질화물계 서멧트의 파괴인성을 개선하기 위 한 방안으로 성공적인 연구 결과가 도출되고 있다. 이러 한 연구를 통해 텅스텐 탄화물과 비교하여 여러 장점(낮 은 비중, 가격 경쟁력 등)을 갖고 있는 타이타늄 탄/질화 물의 활용 범위가 확대될 수 있을 것으로 기대된다.

\section{REFERENCES}

1. P. Ettmayer, "HARDMETALS AND CERMETS," Annu. Rev. Mater. Sci., 19 145-64 (1989).

2. X. H. Zhang, J. C. Han, S. Y. Du and J. W. Wood, "Microstructure and mechanical properties of $\mathrm{TiC}-\mathrm{Ni}$ functionally graded materials by simultaneous combustion synthesis and compaction," J. Mater. Sci., 35 1925-30 (2000).

3. J. Jung and S. Kang, "Effect of ultra-fine powders on the microstructure of $\mathrm{Ti}(\mathrm{CN})-\mathrm{xWC}-$ Ni cermets," Acta Mater., 52 1379-86 (2004).

4. J. Jung and S. Kang, "Effect of Nano-Size Powders on the Microstructure of $\mathrm{Ti}(\mathrm{C}, \mathrm{N})-$ xWC-Ni Cermets," J. Am. Ceram. Soc., 90 [7] 2178-83 (2007).

5. J. Jung and S. Kang, "Sintered (Ti,W)C carbides," Scripta Mater., 56 561-4 (2007).

6. R. Hulyal and G. S. Upadhyaya, "Sintering of WC-10Co Hard Metals Containing Vanadium Carbonitride and Rhenium-Part I: Vanadium Carbonitride Addition," Ref. Met. Hard Mater., 10 1-7 (1991).

7. H. Nam and S. Kang, "Microstructure of (W,Ti) 
C-Co system containing platelet WC," Mater. Sci. Eng. A, 527 7163-7 (2010).

8. Y. Kang and S. Kang, "WC-reinforced (Ti,W) (CN),” J. Eur. Ceram. Soc., 30 793-8 (2010).

9. K. T. Hwang, C. S. Kim, K. H. Auh, D. S. Cheong and $\mathrm{K}$. Niihara, "Influence of $\mathrm{SiC}$ particle size and drying method on mechanical properties and microstructure of $\mathrm{Si} 3 \mathrm{~N} 4 / \mathrm{SiC}$ nanocomposite," Mater. Lett., 32 251-257 (1997).

10. B. Zou, C. Z. Huang, H. L. Liu and M. Chen, “ Preparation and characterization of $\mathrm{Si}_{3} \mathrm{~N}_{4} / \mathrm{TiN}$ nanocomposites ceramic tool materials," $J$. Mater. Proc. Technol., 209 4595-4600 (2009).

11. D. Sciti, L. Silvestroni and M. Nygren, "Spark plasma sintering of $\mathrm{Zr}$ and $\mathrm{Hf}$-borides with decreasing amounts of MoSi2 as sintering aid, "J. Eur. Ceram. Soc., 28 1287-1296 (2008).

12. D. S. Park and Y. D. Lee, "Effect of Carbides on the Microstructure and Properties of Ti(C,N)-Based Ceramics," J. Am. Ceram. Soc., 82 [11] 3150-54 (1999).

13. Cutting Tools; World markets, end-users, and competitors: 2012-2018 analysis \& forecasts, Dedalus Consulting, Inc., 2014

14. A. Moradkhani, H. Baharvandi and A. Naserifar, "Fracture Toughness of 3Y-TZP Dental Ceramics by Using Vickers Indentation, "J. Korean Ceram. Soc., 56 [1] 37-48 (2019).

15. H. J. Kim, S. M. Lee, J. Maeng and D. H. Kim, "Micro-Crack Healing on Soda-Lime Glass by Chemical Strengthening," J. Korean Ceram. Soc., 56 [5] 483-8 (2019).

16. H. G. Jo, H. Kwon and I. J. Shon, Simultaneous Synthesis and Rapid Consolidation of Nanostructured (Ti,Mo)C and Its Mechanical Properties," Kor. J. Mater. Res., 23 [11] 620-4 (2013).

17. S. A. Jung, H. Kwon, K. M. Roh, C. Y. Suh and W. Kim, "Ti-Based Solid Solution Carbonitride Prepared From Ti-Alloy Scraps via a Hydrogenation-Dehydrogenation Process and High-Energy Milling," Met. Mater. Int., 21 [5] 923-8 (2015).

18. J. M. Oh, K. M. Roh, H. Kwon, B. K. Lee, C. Y. Suh and J. W. Lim, "Preparation of Ti
Ternary Alloys by Addition of Si to Ti-Mo Alloy Scraps for Carbonitride Application," Mater. Tras., 56 [1] 167-70 (2015).

19. H. Kwon, S. A. Jung and W. Kim, "(Ti, Cr) C Synthesized In Situ by Spark Plasma Sintering," Mater. Tras., 56 [2] 264-8 (2015).

20. H. Kwon, J. Kim, S. A. Jung, C. Y. Suh, D. S. Kil, K. M. Roh and W. Kim, "(Ti,W)C-Ni cermet prepared by high-energy ball milling and subsequent carbothermal reduction of $\mathrm{TiO}_{2}-\mathrm{Ti}-\mathrm{WO}_{3}-\mathrm{C}$ mixture," Ceram. Int., 40 7607-11 (2014).

21. I. J. Shon, H. G. Jo and H. Kwon, "Properties of nanostructured $\mathrm{TiC}$ and $\mathrm{TiC}-\mathrm{TiAl} 3$ hard materials rapidly sintered by the pulsed current activated heating," Int. J. Ref. Met. Hard Mater., 48 187-93 (2015).

22. H. Kwon and S. A. Jung, "Solid Solution Cermet: (Ti, Nb)(CN)-Ni Cermet," J. Nanosci. Nanotechnol., 14 8823-7 (2014).

23. H. Kwon, J. Kim, S. A. Jung, C. Y. Suh, D. S. Kil, K. M. Roh and W. Kim, "Mechanical properties of $(\mathrm{Ti}, \mathrm{V}) \mathrm{C}-\mathrm{Ni}$ composite prepared using ultrafine solid-solution (Ti,V)C phase," Ceram. Int., 40 12579-83 (2014).

24. H. Kwon, C. Y. Suh and W. Kim, "Preparation of a highly toughened (Ti,W)C-20Ni cermet through in situ formation of solid solution and WC whiskers," Ceram. Int., 41 4223-6 (2015).

25. S. Y. Ahn and S. Kang, "Formation of Core/ Rim Structures in $\mathrm{Ti}(\mathrm{C}, \mathrm{N})-\mathrm{WC}-\mathrm{Ni}$ Cermets via a Dissolution and Precipitation Process," J. Am. Ceram. Soc., 83 [6] 1489-94 (2000).

26. H. Kwon, W. Kim and J. Kim, "Stability domains of $(\mathrm{Ti}, \mathrm{W}) \mathrm{C}$ and $(\mathrm{Ti}, \mathrm{W})(\mathrm{CN})$ during carbothermal reduction of TiO2/WO3 mixture at 1500 K," J. Eur. Ceram. Soc., $371355-71$ (2017).

27. H. Kwon, A. Moon and J. Kim, "Prediction of solid solution characteristics of $\mathrm{MC}(\mathrm{M}=\mathrm{Zr}$, $\mathrm{Nb}$, and $\mathrm{Ta}$ ) in TiC lattice using phase stability diagrams," J. Am. Ceram. Soc., 102 [7] 428595 (2019).

28. H. Kwon, A. Moon and J. Kim, "Phase Stability Diagrams of $\mathrm{Ti}-\mathrm{M}-\mathrm{O}-\mathrm{C}(\mathrm{M}=\mathrm{Zr}$, $\mathrm{Hf}, \mathrm{Nb}$, and Ta) Systems at $1800 \mathrm{~K}$, " Met. 
Mater. Int., 25 396-407 (2019).

29. X. Song, Y. Gao, X. Liu, C. Wei, H. Wang and W. Xu, "Effect of interfacial characteristics on toughness of nanocrystalline cemented carbides," Acta Mater., 61 2154-62 (2013).

30. H. Xie, X. Song, F. Yin and Y. Zhang, Effect of WC/Co coherency phase boundaries on Fracture toughness of the nanocrystalline cemented carbides," Sci. Rep., 6 31047-54 (2016).

31. H. Kwon, J. Kim, S. A. Jung, C. Y. Suh, D. S. Kil, K. M. Roh, W. Kim and J. W. Lim, " Premixed TiC-Ni composite powder prepared by mechanical milling of $\mathrm{Ti}-\mathrm{Ni}$ alloy/graphite mixture and subsequent heat treatment," Powder Technol., 253 681-5 (2014).

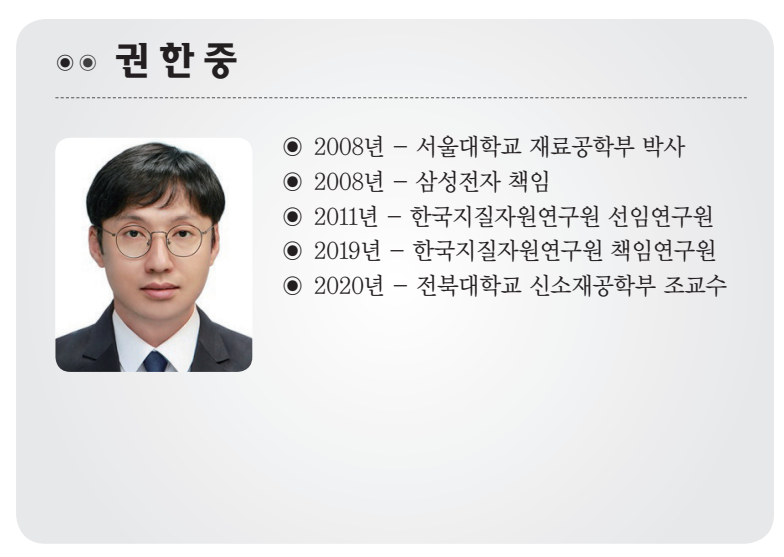

32. H. Kwon, S. A. Jung, C. Y. Suh, K. M. Roh, W. Kim and J. Kim, "Highly toughened dense TiC-Ni composite by in situ decomposition of (Ti,Ni)C solid solution," Ceram. Int. , 41 465661(2015).

33. S. A. Jung, H. Kwon, C. Y. Suh, J. M. Oh and W. Kim, "Preparation of a fine-structured TiC-Co composite by high-energy milling and subsequent heat treatment of a Ti-Co alloy," Ceram. Int., 41 14326-31(2015).

34. H. Kwon and C. Y. Suh, "Effects of Ni content and sintering temperature on the microstructure and mechanical properties of $\mathrm{TiC}-\mathrm{Ni}$ composites fabricated by selective carburization of $\mathrm{Ti}-\mathrm{Ni}$ alloys," J. Alloys Comd., 834155000 (2020). 